\title{
The design of artificial nestboxes for the study of secondary hole-nesting birds: a review of methodological inconsistencies and potential biases
}

\author{
Marcel M. Lambrechts*, Frank Adriaensen, Daniel R. ArdiA, Alexandr V. ArtemyeV, \\ Francisco AtiÉnZAR, Jerzy BAŃBURA, Emilio BARBA, Jean-Charles Bouvier, Jordi \\ Camprodon, Caren B. Cooper, Russell D. Dawson, Marcel Eens, Tapio Eeva, Bruno \\ Faivre, Laszlo Z. Garamszegi, Anne E. Goodenough, Andrew G. Gosler, Arnaud \\ Grégoire, Simon C. Griffith, Lars Gustafsson, L. Scott Johnson, Wojciech KaniA, \\ Oskars Keišs, Paulo E. Llambias, Mark C. Mainwaring, Raivo Mänd, Bruno Massa, \\ Tomasz D. Mazgajski, Anders Pape Møller, Juan Moreno, Beat Naef-Daenzer, \\ Jan-Åke Nilsson, Ana C. Norte, Markku Orell, Ken A. Otter, Chan Ryul Park, \\ Christopher M. Perrins, Jan PINOWSKI, Jiri Porkert, Jaime POTTI, Vladimir Remes, Heinz \\ Richner, Seppo Rytkönen, Ming-Tang ShiaO, Bengt Silverin, Tore Slagsvold, Henrik \\ G. Smith, Alberto Sorace, Martyn J. Stenning, Ian Stewart, Charles F. ThOMPson, Piotr \\ TrYJANOWSKI, Janos TÖRÖK, Arie J. van NOORDWIJK, David W. WINKLER \& Nadia ZIANE
}

\begin{abstract}
*Centre d'Ecologie Fonctionnelle et Evolutive, UMR 5175, CNRS, 1919 route de Mende, 34293 Montpellier Cedex 5, FRANCE, e-mail: marcel.lambrechts@cefe.cnrs.fr

All authors' affiliations - see appendix 2

Lambrechts M. M., Adriaensen F., Ardia D. R., Artemyev A. V., Atiénzar F., Bańbura J., Barba E., Bouvier J.-C., Camprodon J., Cooper C. B., Dawson R. D., Eens M., Eeva T., Faivre B., Garamszegi L. Z., Goodenough A. E., Gosler A. G., Grégoire A., Griffith S. C., Gustafsson L., Johnson L. S., Kania W., Keišs O., Llambias P. E., Mainwaring M. C., Mänd R., Massa B., Mazgajski T. D., Møller A. P., Moreno J., Naef-Daenzer B., Nilsson J.- Å., Norte A. C., Orell M., Otter K. A., Park Ch. R., Perrins Ch. M., Pinowski J., Porkert J., Potti J., Remes V., Richner H., Rytkönen S., Shiao M.T., Silverin B., Slagsvold T., Smith H. G., Sorace A., Stenning M. J., Stewart I., Thompson Ch. F., Török J., Tryjanowski P., van Noordwijk A. J., Winkler D. W., Ziane N. 2010. The design of artificial nestboxes for the study of secondary hole-nesting birds: a review of methodological inconsistencies and potential biases. Acta Ornithol. 45: 1-26. DOI 10.3161/000164510X516047
\end{abstract}

\begin{abstract}
The widespread use of artificial nestboxes has led to significant advances in our knowledge of the ecology, behaviour and physiology of cavity nesting birds, especially small passerines. Nestboxes have made it easier to perform routine monitoring and experimental manipulation of eggs or nestlings, and also repeatedly to capture, identify and manipulate the parents. However, when comparing results across study sites the use of nestboxes may also introduce a potentially significant confounding variable in the form of differences in nestbox design amongst studies, such as their physical dimensions, placement height, and the way in which they are constructed and maintained. However, the use of nestboxes may also introduce an unconsidered and potentially significant confounding variable due to differences in nestbox design amongst studies, such as their physical dimensions, placement height, and the way in which they are constructed and maintained. Here we review to what extent the characteristics of artificial nestboxes (e.g. size, shape, construction material, colour) are documented in the 'methods' sections of publications involving hole-nesting passerine birds using natural or excavated cavities or artificial nestboxes for reproduction and roosting. Despite explicit previous recommendations that authors describe in detail the characteristics of the nestboxes used, we found that the description of nestbox characteristics in most recent publications remains poor and insufficient. We therefore list the types of descriptive data that should be included in the methods sections of relevant manuscripts and justify this by discussing how variation in nestbox characteristics can affect or confound conclusions from nestbox studies. We also propose several recommendations to improve the reliability and usefulness of research based on long-term studies of any secondary hole-nesting species using artificial nestboxes for breeding or roosting.
\end{abstract}

Key words: methods, nestboxes, nest sites, passerines, secondary cavity-nesting birds, field experiments, tit, flycatcher, Ficedula, Parus, Cyanistes

Received — Aug. 2009, accepted — April 2010 


\section{INTRODUCTION}

Half of the avian orders use some form of cavity for nesting or roosting (Gill 2007), with up to $30 \%$ of the bird species present in some locations being cavity-nesters (Newton 1994, Bai \& Mühlenberg 2008). While primary hole-nesters such as woodpeckers are able to excavate their own nest holes in trees, obligate secondary holenesters do not have the physical force to drill large holes in hard wood, although some are capable of modifying or enlarging existing cavities in dead or decaying trees (Newton 1994, Schepps et al. 1999, Martin \& Norris 2007, Atienzar et al. 2009). Consequently, secondary hole-nesters must rely upon natural tree cavities or unoccupied holes excavated by primary hole-nesters (Martin \& Eadie 1999, Remm et al. 2006). Thus, the availability and characteristics of tree holes suitable for secondary hole-nesters is partly influenced by the activity and abundance of primary hole-nesting species, which in turn depend upon the characteristics of the tree species present (e.g. size and age, architecture, hardness) as well as the activity of other taxonomic groups, such as micro-organisms (including fungi), insects, amphibians, reptiles, and mammals (Conner 1977, Wilson et al. 1991, Bednarz et al. 2004, Jackson \& Jackson 2004, Ojeda et al. 2007, Wesołowski 2007, Camprodon et al. 2008, Koch et al. 2008, Lambrechts et al. 2008, Matsuoka 2008). Fluctuations in external factors such as ambient temperature and the intensity and direction of wind or rain can also influence the availability and characteristics of holes (e.g. East \& Perrins 1988, Walankiewicz 1991, Wesołowski et al. 2002). For instance, persistent strong winds or rain may increase the erosion of existing small cavities, blow branches from trees so that new cavities are created, or blow down dead trees containing cavities.

Each natural hole found in a dead or living tree probably has a unique combination of variables, such as the position, orientation and shape of the entrance hole, and the cavity's material, wall thickness, depth, diameter, floor area, shape, colour, volume, internal surface, light conditions and age (van Balen et al. 1982, Nilsson 1984, East \& Perrins 1988, Rendell \& Robertson 1989, Carlson et al. 1998, Czeszczewik \& Walankiewicz 2003, Wesołowski \& Rowiński 2004, Mazgajski 2007b; Table 1). The size or other characteristics of cavities occupied by secondary hole-nesting birds can vary within and between species (Table 1). Studies of these cavities can provide the necessary background data for the better design of research that uses man-made nestboxes (e.g. Nilsson 1975, 1984, Møller 1989, 1992, Wesołowski 2007).

\section{The use of nestboxes to study secondary hole-nesters}

Many secondary hole-nesting species readily breed in man-made artificial cavities, most of which are nestboxes placed against tree trunks, fences or walls, or erected on posts (von Haartman 1969, Kibler 1969, Perrins 1979, Pikula \& Beklova 1980, Newton 1994, Lesiński 2000, Zingg et al. 2010). The use of such artificial cavities in avian research has greatly advanced our understanding of breeding behaviour in cavity-nesting species. Nestboxes allow researchers to perform routine monitoring and experimental manipulation of eggs or nestlings, as well as repeatedly capture, identify and manipulate the parents or offspring (e.g. Sanz 1998, Visser et al. 2003, Both et al. 2004, Griffith et al. 2008). The use of nestboxes often increases the local population of secondary hole-nesters available for study, and it may also help to better control, reduce, or eliminate stochastic effects associated with abiotic factors or predation, thus increasing sample sizes and facilitating data analyses or interpretation. Since the pioneering investigations of G. Wolda in the Netherlands (Kluyver 1951, Lack 1955), artificial nestboxes have been used to aid research in a range of sub-disciplines of the behavioural and environmental sciences e.g. behavioural ecology, cognitive ecology, conservation biology, ecotoxicology, evolutionary ecology, functional ecology, molecular ecology, population ecology (e.g. Busse \& Olech 1968, Perrins 1979, Lundberg \& Alatalo 1992, Koenig et al. 1992, Newton 1994, Schlaepfer et al. 2002, Blondel et al. 2006, Seppänen \& Forsman 2007, Slagsvold \& Wiebe 2007, Mazgajski 2008, Liedvogel et al. 2009, Mänd et al. 2009, Holveck et al. 2010, Van den Steen et al. 2010, Zingg et al. 2010). Nestbox studies have also contributed significantly to the development of lifehistory theory in free-ranging organisms (Clutton-Brock 1988, Newton 1989) because of the ease with which manipulations can be performed. Consequently, secondary hole-nesting passerines have become one of the most intensively investigated free-living bird groups of the world (e.g. Riddington \& Gosler 1995), and occupy top positions with respect to the total number of papers returned by two ISI Web of Science searches of passerine studies by common and scientific name 


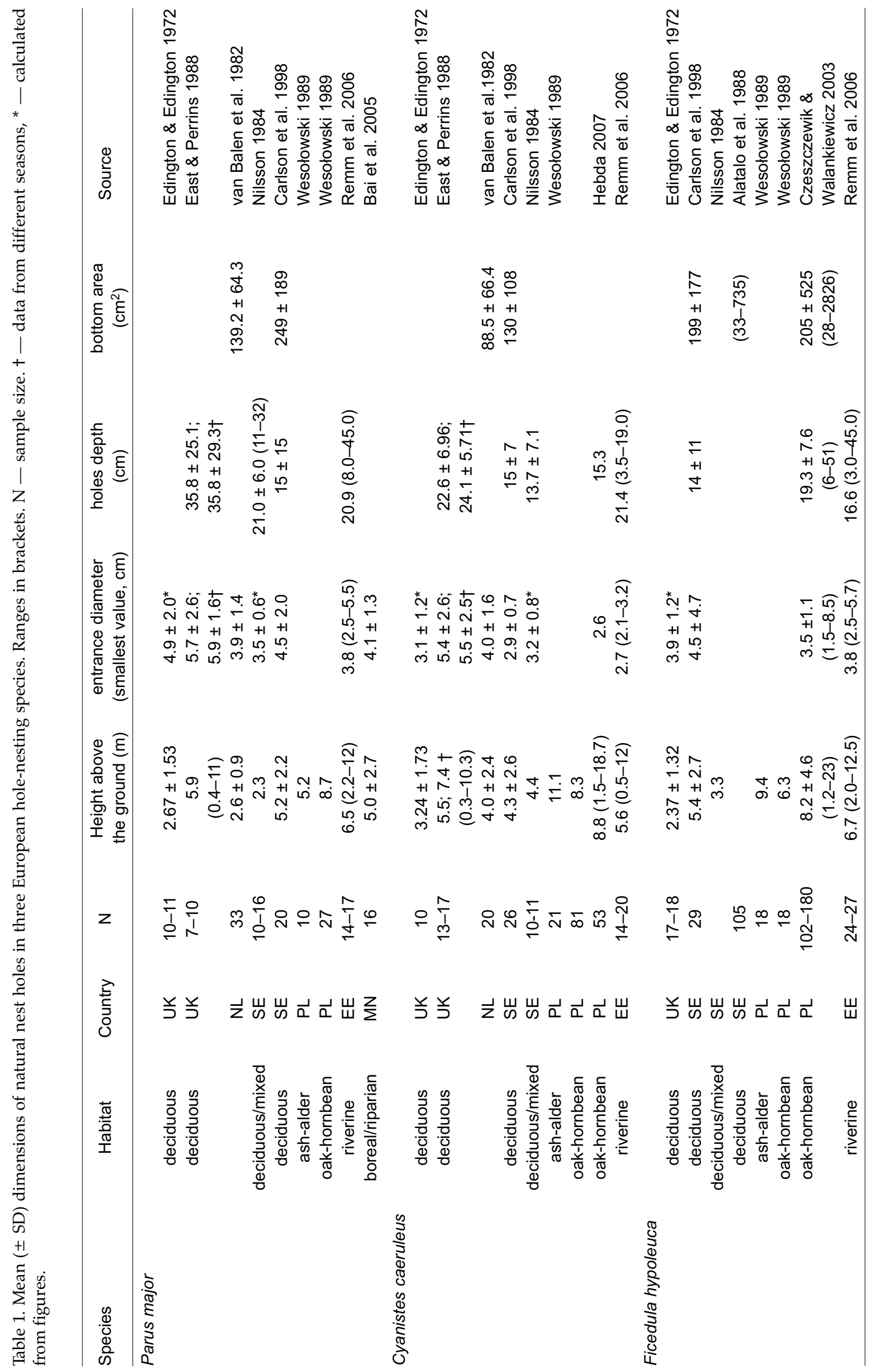


(Average number of publications of the two searches in 2010 for cavity-nesters: Parus major 1807, Sturnus vulgaris - 1293, Passer domesticus 999, Ficedula hypoleuca - 880, Cyanistes caeruleus 756, Tachycineta bicolor - 744, Sialia sialis -414 versus non-cavity nesters: Hirundo rustica - 663, Melospiza melodia - 609, Agelaius phoeniceus - 488, Carpodacus mexicanus - 335).

However, studies involving birds breeding in nestboxes have been criticized on the grounds that the boxes differ in several ways from natural or excavated cavities, and that avian research in free-ranging populations is overwhelmingly dominated by a few 'classic' model systems. Consequently results derived from these studies may fail to reflect natural variation potentially reducing their general validity or applicability (e.g. Nilsson 1975, Møller 1989, 1992, but see Koenig et al. 1992, Wesołowski 2007). For instance, van Balen et al. (1982) cites the main difference between natural holes and artificial nestboxes erected in the same location as a higher rate of nest failure in natural holes because of water logging or competition from bigger animals, factors that are often excluded when nestboxes are used. Whether nestboxes are safer than natural cavities from nest predators or competitors may depend on differences in height or positioning between artificial and natural cavities (Nilsson 1984, McCleery et al. 1996), or whether protective devices have been added to the nestboxes to reduce predation. For instance, metal plates or wire mesh fitted around the entrance hole of nestboxes may prevent the hole being enlarged by woodpeckers or mammals, and pipes placed in the entrancehole may prevent predators from reaching the contents. Also, treating wooden nestboxes with chemicals, such as preservatives or pesticides, may prevent them from decay due to fungal rot or burrowing arthropods (e.g. Kibler 1969, Nilsson 1984, McCleery et al. 1996, Miller 2002, Mainwaring \& Hartley 2008, Skwarska et al. 2009).

Nestboxes are also designed so that researchers can frequently inspect their contents which may cause rapid changes in the chemical environment within the nest (e.g. $\mathrm{CO}_{2}$ concentrations influencing attractiveness of flying insects exploiting avian hosts - see Tomás et al. 2008) or micro-climate that do not occur in natural or excavated holes. Nestbox studies may also be prone to biased sampling because they may only be occupied by individuals or species that accept artificial cavities, while the remainder retain a preference for natural or excavated cavities (Dhondt 2007). The proportion of individuals that use either natural or artificial holes may therefore depend on the difference in quality between the two or the distribution of individual preferences for different breeding sites. The interval between the placement of nestboxes and the start of a study may also result in biased sampling. For instance, if nestboxes are initially erected just a few weeks before the start of the breeding season of resident species, nonterritorial first-year birds may be attracted to study sites that do not provide opportunities for winter roosting in natural cavities.

While there are many benefits of the intensive study of model species, there is an obvious danger of basing our general understanding of birds on such a small number of cavity-nesting species that share a similar ecology and are mostly located in just one region of the world (Europe). To date, while there are many studies of a variety of holenesters in North America they have not dominated the literature to the same extent as have the European studies (e.g. see also Chamberlain et al. 2009). There are whole regions of the world in which nestboxes have never been used, although studies have recently been published on avian nestbox exploiters in Australia (Griffith et al. 2008), Argentina (Massoni et al. 2006, Cockle \& Bodradi 2009, Llambias \& Fernández 2009), Chile (Moreno et al. 2005, 2007) and China (Wang et al. 2008) (but see for instance older studies in Tryjanowski et al. 2006 and Evans et al. 2009 for New Zealand or Eguchi 1980 for Japan). It should also be pointed out that nestboxes in some countries are widely distributed throughout the countryside by forestry administrations or environmental organizations (e.g. Poland, Spain). For instance, thousands of nestboxes of a specific design have been erected for $>50$ years in many Polish and Spanish forests, constituting an unavoidable part of the environment for hole-nesters that does not depend on researchers and that may have induced significant selective pressures on populations.

There exist biases in the material used (e.g. nestbox design), the choice of the model species, and the environment (e.g. European woodland) in which research is conducted. The extent to which all this is really a problem is difficult to evaluate since few studies have compared biological aspects of birds which breed in nestboxes and those which breed in natural or excavated cavities at the same location (but see e.g. East \& Perrins 1988, Johnson \& Kermott 1994, Miller 2002, Llambias \& Fernández 2009 and references 
therein). However, this issue can be evaluated indirectly by examining whether the characteristics of artificial nestboxes and their occupants differ from those of natural or excavated nestholes (e.g. Dhondt 2007), and if there are differences, whether these would affect the likelihood of supporting or rejecting a particular hypothesis.

\section{The ecological significance of variation in nest- box characteristics}

Several studies indicate that the characteristics of each nestbox influence the physical environment (e.g. ambient temperature, humidity, light reflectance) or biotic environment (e.g. presence and biology of other organisms, parent-offspring interactions) within the nest-chamber, and therefore the development or survival of the eggs or nestlings, or the survival or physical condition of adults using nestboxes for reproduction or roosting (Löhrl 1973, van Balen 1984, Slagsvold \& Amundsen 1992, Mazgajski 2007a, Dhondt et al. 2010). The internal size of the nest cavity may also influence clutch size, depending on the size ranges of the nest-chamber or species involved (e.g. Karlsson \& Nilsson 1977, Moeed \& Dawson 1979, Löhrl 1980, van Balen 1984, Gustafsson \& Nilsson 1985, Slagsvold \& Amundsen 1992). In Great Tits Parus major, for instance, an experiment in which nestboxes were replaced with a different-sized box shortly after the onset of egg laying found that size differences in subsequently-produced clutches may be as large as the variation in clutch size observed across distinct forest types (e.g. > 2 eggs, Löhrl 1973, 1980, Sanz 1998). In Pied Flycatchers Ficedula hypoleuca, this may not be related to an adjustment of clutch size to cavity size per se, but could for example result from females laying larger clutches selecting larger cavities for breeding or spending more time to find a large nest cavity (Slagsvold 1987).

Several other variables seem intuitively likely to affect whether a nestbox is occupied, and if so, the success of each breeding attempt. For example, erecting boxes of varying dimensions at the same location has shown that different individuals or species use cavities with different characteristics. The size and position (e.g. height, orientation) of the entrance hole appears to determine which individual or species will occupy nestboxes and how their life-history traits will be expressed in the presence of other organisms (e.g. Kluyver 1951, Nilsson 1984, Barba \& Gil-Delgado 1990, Dhondt \& Adriaensen 1999, Zingg et al. 2010). For example, large individuals or species cannot enter small entrance holes or nestbox chambers simply because of physical constraints. Furthermore, smaller individuals or species may prefer to breed in nestboxes with small entrance holes, particularly those located high in trees, to reduce risks related to predation or competition (Löhrl 1970, 1977, Slagsvold 1975, Nilsson 1984, Newton 1994, Sorace $\&$ Carere 1996).

A given nestbox type may be preferred in one environment and yet disfavoured in another. For instance, local meteorological effects may influence the preferences for certain nest-cavities with birds avoiding those with holes oriented in the direction of prevailing wind or rain (e.g. Goodenough et al. 2008). Orientation of nests has been found to influence site selection of natural cavities and artificial cavities in Tree Swallows Tachycineta bicolor (Rendell \& Robertson 1994, Ardia et al. 2006), probably because internal nest temperatures differ as a function of orientation (Ardia et al. 2006). Orientation of occupied nestboxes may also be influenced by the location of conspecifics (Mennill \& Ratcliffe 2004). According to Kluijver (1951), cavity preferences may differ between males and females and vary seasonally. Birds may only avoid nestboxes with larger holes in areas with high perceived predation risk (e.g. Sorace \& Carere 1996). The cleaning practices of nestboxes may also affect the choice of nestboxes. (Mazgajski 2007a). For example, Pied Flycatchers may gain time benefits in nest building if the old nest is not removed (Orell et al. 1993, Mappes et al. 1994), House Wrens Troglodytes aedon may prefer nestboxes containing old nests because they provide evidence of previous success at that location (Johnson 1996, Pacejka \& Thompson 1996), or Great Tits may avoid nestboxes containing old nests with many fleas (Rytkönen et al. 1998). Thus, the choice and location of nestbox type may interact with other environmental factors, such as the availability and properties of natural cavities, and significantly influence the outcome of ecological field investigations.

To examine whether scientists working with secondary hole-nesting passerines have acknowledged the significance of variation in nestbox design, we assessed whether nestbox characteristics have been documented in the 'methods' sections of publications or incorporated into statistical analyses of long-term databases. We also discuss how variation in nestbox characteristics can affect or confound conclusions from nestbox studies and propose several recommendations to improve future research. 


\section{METHODS}

Three papers published over 15 years ago discussed the potential artefacts associated with the use of nestboxes, but also emphasised that many scientists simply did not report what they did with their nestboxes (Møller 1989, 1992, Koenig et al. 1992). Field ornithologists were urged to: 1) improve the design of their nestboxes so that they mimic more closely the characteristics of natural or excavated holes and 2) describe the characteristics of their boxes and the procedures used for maintaining boxes to allow for the exact replication of protocols across studies (see also Kelly 2006). To assess whether subsequent investigations followed these recommendations, we examined the methods section of publications involving the most commonly investigated hole-nesting birds. We divided the papers into two groups: those published before the recommendations of Koenig et al. (1992) and Møller (1992) ("older" publications), and those published from 1992 onwards ("more recent" publications). Based on the recommendations of Møller (1989), we predicted that descriptions of nestbox characteristics would be more frequent among articles published from 1992 onwards. We located relevant publications by using the common or scientific (current or older) names of secondary hole-nesting passerines as key words in the leading electronic databases (ISI Web of Science, Biblio-Vie, BiblioSHS) and also searching the extensive collection of reprints possessed by $P$. Isenmann (CEFEMontpellier). We searched the reference section of each of these publications to identify other relevant publications that we had not previously encountered because they were not electronically indexed. We are aware that publications are often not independent units, but we have chosen this entity because it does give the probability that a new reader misses the relevant information in the first paper they read. We surveyed a total of 696 publications from 108 different journals, of which $594(85 \%)$ involved a single species. These publications concerned 12 frequently investigated secondary hole-nesting species, most of which were Eurasian tits (Paridae) or old world flycatchers (Muscicapidae) (Fig. 1).

\section{RESULTS AND DISCUSSION}

Our review produced four main results, leading to the overall conclusion that nestbox characteristics are variable and often unreported in the scientific literature and that the significance of these characteristics is often either ignored or underappreciated.

\section{Detailed descriptions of nestbox properties are often lacking in recent publications}

Around $40 \%$ of the older publications $(<1992)$ on passerine secondary hole-nesting birds that we assessed did not provide information on nestbox characteristics and did not reference a former publication providing this information (Fig. 1). This value is even higher (70\%) for the verified studies published since 1992. Even when descriptions were provided, they were usually incomplete. For instance, of 94 instances where one nestbox characteristic was mentioned, $58 \%$ gave only a broad description of the material used (wood, wood-concrete, concrete), and only $25 \%$ gave the diameter of the entrance hole. The tree species used to construct wooden nestboxes or the thickness of the nestbox wall were rarely mentioned (e.g. Michelsons 1958, Delmée et al. 1972, Finch 1989 for exceptions), even though both may influence the thermal or chemical environment of the nest cavity, and thus directly or indirectly affect the physiology of eggs, nestlings or adults (e.g. Kibler 1969, Mertens 1977, 1980, van Balen 1984, Korpimäki 1985, Dawson et al. 2005, García-Navas et al. 2008, Nilsson et al. 2008, Ardia et al. 2009). For instance, there is empirical evidence that invertebrate communities and microorganisms are both affected by their host tree species or its natural compounds, or chemical compounds applied to the wood from which the box was constructed, such as preservatives (e.g. Janzen 1978, Balandrin et al. 1985, Chapuisat et al. 2007, Sipponen et al. 2009, Blondel et al. 2010), and that invertebrate communities in the nest may influence avian life-history traits (e.g. Sengupta 1981, Heeb et al. 2000, Mennerat et al. 2009). Some authors supplied dimensions without specifying whether these refer to the size of the whole box (exterior) or just the nestbox chamber (interior). The biological importance of light incidence inside nestboxes has been ignored for many years, and therefore, rarely, or not reported. For instance, in nestboxes used in several studies in Spain (e.g. Moreno et al. 2006, 2008) the removable frontal lid does not cover the whole front but leaves a slit of $1-1.5 \mathrm{~cm}$ which allows luminous conditions within nestboxes. Light conditions within the nestbox chamber may influence the expression of signals possessed by the eggs or 


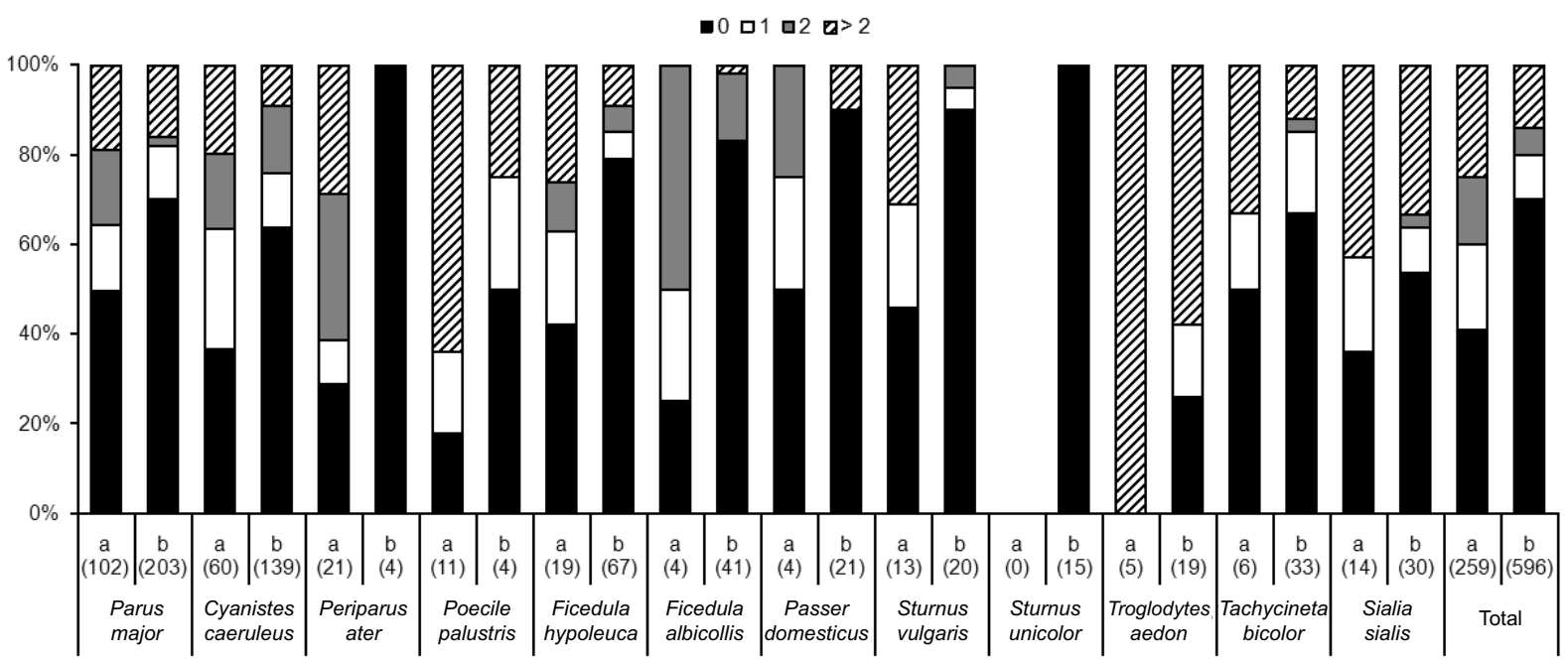

Fig. 1. Percentage of publications describing or citing 0 or more nestbox characteristics in analysed papers in two publication periods: $\mathrm{a}-<1992, \mathrm{~b}-\geq 1992$. The percentage of publications with information on none (0) one (1), two (2) or more than two $(>2)$ nest-box properties are indicated, which includes the publications citing references providing the information in the methods section. Number of papers in parenthesis.

nestlings addressed to parents or social mates (e.g. Holveck et al. 2010). Since natural or excavated tree holes used by secondary hole-nesting birds can be described using at least 10 different parameters (Kibler 1969, van Balen et al. 1982, East \& Perrins 1988, Carlson et al. 1998, Remm et al. 2006), perhaps these same parameters could be defined and standardized, then used to describe artificial nestboxes in widely understood details, as architects do when designing buildings.

\section{Nestboxes often represent only a small fraction of the properties of natural holes}

The nestboxes erected in most study sites are usually identical in shape and dimensions. Although the nestboxes were probably made to a consistent design in order to minimize potential confounding variables and maximize sample sizes (e.g. Drilling \& Thompson 1988, McCleery et al. 1996, Llambias \& Fernández 2009), the scientific rationale for using a particular type of nestbox, for mounting and positioning them in a particular way, or for protecting them from predators is often not provided. This is a particular problem when nestboxes possess physical properties that significantly differ from those of tree cavities (e.g. Nilsson 1975, Karlsson \& Nilsson 1977, Moeed \& Dawson 1979, Alatalo et al. 1988, Møller 1989, 1992, Purcell et al. 1997) and nestbox characteristics selected to initiate a long-term study significantly influence the results of ecological investigations (e.g. McCleery et al. 1996, García-Navas et al. 2008).
It should be noted though that the continuity of nestbox characteristics and placements in some study sites can lead to in-depth research where confounding (changeable) factors are controlled (e.g. nestbox orientation, Goodenough et al. 2008).

\section{Different research teams often do not use the} same nestbox designs and research protocols

Different research groups studying hole-nesting birds in different locations rarely use the same type or size of nestbox, even when studying the same species (see Appendix 1). There may be several economic or scientific reasons for such variation in nestbox design. The material used to construct nestboxes in each location may depend on local availability or price (Moeed \& Dawson 1979), or on decisions taken by forestry administrations or environmental organisations without consulting researchers regarding the massive distribution of a certain type of nestbox (e.g. Spain), or may have been proven to be optimal by local ornithological organisations (e.g. Baucells et al. 2003). Consequently, if nestboxes are designed with particular characteristics because of local environmental conditions, such as the use of thick-walled boxes in areas with more extreme weather conditions, then nestboxes should be more variable in species with a larger distributional range. Although we did find large-scale variation in nestbox characteristics among research teams studying the same species, there was little scientific justification for this, as this variation was not intend- 
ed to better understand biological consequences of 'nestbox-environment' interactions at broad spatiotemporal scales. Replicates in nestbox design across study sites are currently often segregated instead of properly interspersed. Furthermore, nestbox characteristics may also differ within local populations, as some nestboxes are replaced after several years or different boxes may be erected as new breeding plots are established. However, it has to be noted that nestbox design or placement may be constrained by the need to avoid human predation or destruction of nests in certain countries. For instance, in Spain nestboxes are erected at $>3 \mathrm{~m}$ above the ground to avoid citizens collecting nests or eggs (but see e. g. nestbox research in orange monocultures in eastern Spain, Monrós et al. 1999), in other areas people collect nestboxes to adorn houses and gardens, and in Kenya people search nestboxes to collect honey.

There are several potential consequences of research teams failing to use the same nestbox design. For example, different nestbox types necessitate the use of different devices for capturing birds. A box opened through the roof (e.g. Wageningen box, van Balen 1984) probably will require a different trapping device than a box opened through a front door (Schwegler type, see www.schwegler-natur.de, Blondel 1985) (Gosler 2004, M. Lambrechts pers. obs.). The use of distinct types of boxes may also influence the time devoted to measuring or manipulating certain traits such as nest characteristics. There may be biological consequences of the different capture or monitoring techniques required for each type of box, since some may be more stressful to the captured birds than others. Furthermore, avian personalities or other phenotypic traits may differ between studies because certain types of nestbox may influence whether they attract relatively "shy" or "bold" individuals (see Garamszegi et al. 2009). In addition, the activity of researchers, such as the frequency of box-monitoring, parent capture and release behaviour (i.e. relative to chick age, and using mist nets or box traps), may all affect the level of desertion or the rate at which parents feed their chicks (and hence growth rates and offspring condition). Direct researcher effects may be limited in populations in which adults are more resistant to disturbance, as a result of conditioning (where individuals become habituated to nestbox design-related research methods over their lifetimes), or even potentially, and perhaps more interestingly, by selection over generations (e.g. Møller 2010).
Wooden nestboxes have to be treated more frequently with chemicals than those built from concrete or a mix of wood and concrete (e.g. Schwegler boxes), and may also have to be replaced more frequently. In long-term studies, replacement boxes should be erected in the same exact location as the previous box or else there may be a change in their local environment, for instance changing the risk of predation (e.g. Sonerud 1989, Sorace et al. 2004) or exposure to weather conditions (e.g. Goodenough et al. 2008). However, keeping the box environment unchanged may not be possible in commercial forests due to frequent habitat alterations by forest practices (see below).

Some unwanted variation in experimental design complicating data interpretation could be avoided using consistent nestbox characteristics across study populations or periods (e.g. "exact" replication of nestbox design, Hurlbert 1984, Hairston 1989, Kelly 2006). For instance, if different study sites containing identical nestboxes, differ significantly in average clutch size, as is the case in Blue Tits (e.g. Isenmann 1987), it is unlikely that the smaller clutch sizes were physically constrained by the size of the nest-cup (e.g. Slagsvold 1989), assuming that geographic variation in clutch size does not result from spatial variation in monitoring protocols. However, the same nestbox set up does not allow us to exclude the hypothesis that the size of the nest cup, physically limited by the size of the nestbox chamber, limits the production of clutches larger than those observed in the nestboxes used. Perhaps a design replicating more than one nestbox type, and standardising monitoring protocols, across study populations or periods could better test some hypotheses dealing with causal relationships between nestbox design and life-history traits.

\section{Variation in nestbox characteristics is often ignored in statistical analyses}

Nestbox properties may act as confounding factors that should be considered as covariates in statistical analyses of variation in individual or population characteristics. However, most previous comparative studies of phenotypic traits in secondary avian hole-nesters have not included nestbox design as a factor in statistical analyses (e.g. Järvinen 1989, Sanz 1998, 2003, Encabo et al. 2002, Both et al. 2004). This was apparently because variation in nestbox characteristics was assumed to constitute random noise or because 
information on nestbox design was unavailable. For instance, the nestboxes used since the 1950s to study tits in Wytham Wood, Oxford, were altered in the 1970s to make them more resistant to damage from Great Spotted Woodpeckers Dendrocopos major and to significantly reduce the impact of weasels Mustela nivalis entering nestboxes (Perrins 1979). These changes in how nestboxes were constructed (e.g. first from wood then a mixture of wood and concrete) and positioned (initially attached directly on the trunks, later removed from the trunks and suspended from branches) resulted in a rapid temporal shift in life-history traits in Great Tits both at the individual and population level (McCleery et al. 1996, Julliard et al. 1997), a finding apparently ignored in more recent analyses of the long-term database from Oxford. The biological consequences of variation in nestbox design or position could be investigated if future publications would provide details on nestbox characteristics. The non-exhaustive list of designs and positions of nestboxes presented in Table 3 could thus be exploited in future comparative analyses to test for the relative importance of nestbox design and other environmental factors (e.g. population density or composition, presence of other organisms) in the expression of individual life-history traits. Perhaps variation in nestbox characteristics (e.g. nest-chamber size) across most study sites used are often too narrow to become significant confounding factors in many comparative analyses that combine data from different research teams. However, this does not exclude the possibility that variation in nestbox design may become a significant confounding variable when study systems would better reflect the observed variation in characteristics of exploited natural or excavated cavities (see Introduction).

CONSTRAINTS ON REPLICATION OF 'NESTBOX DESIGN - ENVIRONMENT' INTERACTIONS

There are many environmental factors associated with nesting cavities that affect the life-history or phenotypic traits of adults or offspring directly or result from an interaction with the characteristics or position of the nest cavity. For instance, exposure to wind may be a dominant factor in coastal sites, whereas in mountainous terrain or northern regions, variation in altitude and solar exposure may create major environmental differences over small distances. Moreover, the continual growth of trees and forests means that the environment can change significantly during long-term investigations at the same study site. Forest management practices, particularly the removal of old or dead trees that contain excavated or natural holes, will have major effects on the bird species present due to rapid changes in cavity availability, which may influence other biological interactions at intraspecific and interspecific levels (e.g. Newton 1994, Quine et al. 2007, Webb et al. 2007, Wesołowski 2007, Camprodon et al. 2008, Cornelius et al. 2008, Blondel et al. 2010). Habitats shared with humans (e.g. city parks, suburban gardens) during the breeding season may be more likely to be occupied by individuals not disturbed by the presence of human activity (Remacha \& Delgado 2009, Møller 2010). The fact that characteristics of the habitat and densities of excavators and secondary hole-nesters may be influenced by anthropogenic activities means that the characteristics of natural cavities used may not (always) mirror the situation in areas that are relatively unaffected by humans, where they still exist. Black-capped Chickadees Poecile atricapillus, for example, will readily utilize nestboxes in urban landscapes where natural cavities are scarce, and even accept fairly unusual nesting substrates (e.g. hollow fenceposts, Smith 1991). This same species shows low acceptance of these same nestboxes in mature forests where ample natural nesting sites exist (K. Otter, unpublished data). The same is true for Willow Tits Poecile montanus, which do not accept nestboxes in northern Finland (i.e. they excavate new holes in decaying stumps each year, Orell \& Ojanen 1983), but readily use special nestboxes filled with coarse saw-dust in southern Sweden (von Brömssen \& Jansson 1980). Thus studies of birds nesting in cavities in anthropogenically modified habitat may not be an ideal basis for generalisations about the best design, placement and management of nestboxes. Thus, there are limits to replicating studies in different areas and to what can be and should be included in the description of the study.

Perhaps the existence of logistic constraints on exactly replicated research in free-ranging populations may justify the use of experiments in seminatural conditions better controlling for possible interactions between nestbox characteristics and the social or physical environment surrounding the boxes (e.g. Kempenaers \& Dhondt 1991, Velky et al. 2010, but see Lambrechts et al. 1999). The recommendations presented below are intended to 
be a minimum list, and the main purpose of the list is to reduce the likelihood that differences between studies are not an artefact of differences in the characteristics of the nestboxes used. Authors are therefore urged to describe all those aspects of their study sites they consider relevant in comparison to other sites.

\section{List of recommendations}

We urge authors, referees and editors to ensure that the following information is accessible or provided in future publications, or at least as an online supplement:

1. Nestbox dimensions (e.g. Table 3). Include a minimum amount of information on nestbox design, including size and position of the entrance hole, thickness and material of nestbox walls, and width, breath, and height of the internal chamber; 2. Location of nestboxes. Report the position of nestboxes (e.g. placed against tree trunks or hanging from a branch attached to a cable or metal hook), including height, supporting structure (tree, wall, post), orientation, the average distance between neighbouring boxes and their density (number of boxes per ha);

3. Maintenance procedures of nestboxes. Report whether and when old nests are removed, and whether nestboxes or nests are treated to remove parasites or microorganisms (e.g. pesticides, micro-wave treatments, rot prevention chemicals). Perhaps most importantly, researchers should report whether nestboxes are cleaned out before each new nesting season (e.g. to remove winter nests from secondary hole-nesting mammals). The use of weather protection devices should also be mentioned. It should be noted if boxes are removed from the study sites between each breeding season. Because old or damaged boxes are often replaced by new boxes, a study site can contain nestboxes differing widely in age, which should be noted.

4. Protection of nestbox occupants. If the nestboxes incorporate any anti-predator features, including devices to reinforce entrance holes (e.g. metal plates), or to prevent predators from entering the nestbox chamber (e.g. pipes to lengthen the entrance) they should be mentioned.

5. Inspection of nestboxes. Report how frequently (and for how long) nestboxes are opened to allow the contents to be inspected, whether they open at the front, side or the roof, and whether any nestbox traps are used to capture the occupants. In addition, it would be useful to know how long the study has been operating in this way, the overall level of desertion of reproductive attempts and the degree of adult and natal philopatry, as these will all potentially contribute to the strength of conditioning or selection on the breeding adults at the site.

6. Study-site characteristics. Report abiotic and biotic factors at local study sites which could conceivably affect 'nestbox-environment' interactions. Report the frequency of artificial holes relative to the frequency of natural or excavated holes, or if this is impossible (e.g. for holes $>10 \mathrm{~m}$ high or in forest with difficult topography or dense understory) provide at least data about the dominant tree species, age of tree stands, and the proportion of nestboxes occupied. The availability of similar or different nestboxes in the general geographic area should also be given if possible, as people other than researchers erect nestboxes in many countries. To assess the representativeness of the biological samples taken from the nestboxes, a reference survey to assess properties of natural holes could be carried out in each nestbox plot. Research is needed through which information on the phenotypic traits of interest is obtained from breeders in natural or excavated holes and these traits are compared with that of birds breeding in nestboxes. It should also be noted whether there are any particular habitat management practices (e.g. selective logging of trees) or patterns of habitat use (common or occasional recreational areas during the breeding season), which could affect the birds' biology.

\section{PERSPECTIVES}

Future research projects dealing with biological consequences of variation in one or more nestbox characteristics could either focus on preferences of birds for particular nestboxes or on the biological consequences of the choice of particular types of boxes. For instance, insectivorous birds which are capable of laying many eggs may prefer to breed in large nestboxes if hole size provides reliable information about tree trunk diameter and canopy size, which could influence the availability of defoliating insects required to rear the chicks. Birds may reduce their clutch size in small nestboxes in order to adjust the number of eggs laid to the size of the nest cup, thereby improving incubation behaviour, reducing sibling competition for limiting space within the nestbox-chamber or reducing problems related to hyperthermia in hot environments (e.g. van Balen 1984). Testing 
these competing hypotheses about nestbox choice or adjustment of life-history traits after a nestbox has been accepted will require different types of experimental design, which have been conducted or proposed in former investigations (e.g. Löhrl 1973, 1980, García-Navas et al. 2008). Studies looking at preferences could erect two or more nestbox types close together, such as on the same tree (e.g. Bortolotti 1994), to better control for variation in environmental factors other than nestbox design. Quantifying parental or territory characteristics at the same time may test whether preferences for particular nestboxes (e.g. of a given orientation) are adjusted to particular phenotypic characteristics of the parents or the territory (e.g. dominant wind direction). Studies looking at the consequences of occupying a particular nestbox type while controlling for biases due to nestbox preferences could allow birds to settle on a territory then change nestbox types. These field studies should ideally avoid experimentally induced biases caused by nest desertion as much as possible. Research protocols should also be adjusted to the life-histories of the biological models involved, which may require preliminary investigations before adequate experimental protocols can be performed. For instance, the consequences of differences in nestbox design for roosting can only be studied in populations where roosting in nestboxes has been confirmed (e.g. Dhondt et al. 2010).

Nestbox characteristics $(>10)$, parental phenotypes (age, behaviour, physiology, morphology, genetics), habitat charactertistics (e.g. presence of other organisms, local climate, light conditions, type of habitat, social factors, resources, population density and composition) and fitness components (e.g. laydate, clutch size, egg characteristics, egg hatching success, brood size, fledging success, offspring phenotypes) may interact in a complex manner, so there are ample opportunities for development of research projects in different parts of the world aimed to better understand these complex relationships. What follows is a short list of topics that could be developed in future research or education projects.

\section{The biological consequences of existing varia- tion in nestbox design}

Different research teams use replicates in nestbox design that are currently often segregated, so that biological consequences of existing spatial variation in nestbox design cannot always be properly investigated. Existing spatial variation in nestbox design could be redistributed across study sites so that design replicates become properly interspersed. For instance, the effect of differences in nestbox material commonly used (wood versus a woodconcrete mix) could be investigated in local study plots following the experimental designs proposed above (e.g. García-Navas et al. 2008).

\section{The biological consequences of nestbox size in heterogeneous environments}

Previous field investigations focusing on the life-history consequences of nest-chamber size have usually only compared two nestbox size classes (e.g. Löhrl 1977, van Balen 1984, Slagsvold \& Amundsen 1992, but see e.g. Moeed \& Dawson 1979, Korpimäki 1985) often without taking environmental or social factors into account. If bigger nestbox chambers would result in larger broods, then smaller nest-chambers which cause birds to produce smaller clutches may improve fledging success because of a reduction in brood size, especially in poor habitat or younger forest patches. If larger boxes would always be preferred regardless of the richness of the habitat, the hypothesis that large nestboxes can become severe ecological or evolutionary traps in poor habitats can be experimentally tested, both at the individual (Schlaepfer et al. 2002, Robertson \& Hutto 2006) and population level (Schlaepfer et al. 2002, Mänd et al. 2009). These investigations require simultaneous studies of the proximate mechanisms involved in nestbox choice (e.g. genetic, environmental or historical basis) and the fitness consequences of the choice of a particular nestbox type in different environmental conditions (e.g. many versus few food resources).

\section{The biological consequences of the nestbox chemical environment}

The biological consequences of variation in the types of wood used for the construction of nestboxes have to our knowledge not been experimentally investigated. In North America, Western Red Cedar Thuja plicata is often advocated for nestboxes on hobbyist websites. This wood is commonly used to line trunks and wardrobes due to the aromatics it omits deterring moths, and it likely has an effect on insect colonization of nestboxes as well. The different types of wood (e.g. oak versus pine versus exotic) and the chemical compounds they contain may influence the species assemblage of invertebrates and microorganisms that colonize nestboxes, and thereby potentially interact with the avian 
occupants. These effects may be intensified in older nestboxes that are not cleaned by researchers or are rarely opened for monitoring.

\section{Nestbox design, perceived microclimate and biological consequences}

Several nestbox characteristics, such as wall thickness, or the material (e.g. García-Navas et al. 2008) or colours used for the construction of nestboxes, may influence the nature and stability of the nest microclimate and therefore the functioning and interactions amongst organisms occupying these cavities. The nestbox characteristics which are more likely to insulate parents, eggs and offspring against these environmental fluctuations will likely differ across latitudes or altitudes, which could be investigated with both observational and experimental approaches, also within the framework of climate change. If the presence of old nests favours roosting conditions in winter (Pinowski et al. 2006), then nestbox maintenance procedures may influence climatebird interactions at the time of nestbox occupation (e.g. García-Navas et al. 2008 for arguments in the methods).

\section{Effects of different combinations of nestbox characteristics}

An experimental design using different nestbox characteristics as treatments should ideally alter box characteristics in such a way that the 'optimal' nestbox shape for given individuals, territories, populations or habitats can be identified with high precision. This approach calls for field experiments combining different nestbox properties to better reflect variation in natural or excavated holes exploited. It would require a large increase in the number of nestbox types to be erected within or across study plots. As an example, a design combining three classes in wall thickness, cavity depth and cavity width (small, intermediate, and large values), varying independently of each other among nestboxes, would require 27 different nestbox types. In addition, each type should be sufficiently replicated either within or across study populations for the quantification of intra-nestbox type (random) variation. These boxes should ideally be erected "randomly" in a local plot following the designs A1-A3 described in Hurlbert (1984) or experimental designs proposed above. Such an experiment would provide unique opportunities for the study of phenotypic plasticity in life-history traits, with nest-cavity characteristics perhaps to be considered as physical constraints imposed on the plasticity of nest building-dependent life-history traits. Such a project has been conducted before (Korpimäki 1985).

\section{Nestbox design and nest building}

Secondary hole-nesters accepting cavities initially created by other species often have more complex nests than do primary hole-nesters. If nests from secondary hole-nesters are adjusted in response to shortcomings in nest-cavity characteristics, the consequences of interactions between nest structure or composition and nestbox characteristics could also be investigated. For instance, bigger nests may be built in artificial nestboxes with a thinner or colder nestbox wall (e.g. Nager \& van Noordwijk 1992), perhaps to provide more efficient protection against meteorological fluctuations in colder environments (Pinowski et al. 2006). Larger nests appear to be sexually selected in birds in general (e.g. Soler et al. 1998), and small hole chambers may prevent the full expression of this phenotypic trait. Larger nests built in larger/deeper nestboxes (cf. Mazgajski \& Rykowska 2008) may also contain and develop larger populations of ectoparasites (e.g. Tripet \& Richner 1997) or other invertebrates. All this suggests that causal relationships between nestbox characteristics, nest characteristics and avian characteristics may be complex, deserving further study.

\section{Research protocols, avian selection and condi- tioning}

Different research teams do not always use the same procedures for catching birds or monitoring nestbox contents. What are the effects of researchgroup dependent behaviours on bird populations breeding or roosting in artificial nestboxes? Do different regimes of catching and monitoring result in different levels of brood desertion or condition? If adults are caught in a nestbox while feeding chicks, are they more cautious when entering the nest in the future, relative to birds caught in a mist-net outside the box? Perhaps these researchgroup effects may lead to consistent differences in fitness components across study sites or research groups. Avian conditioning to researcher effects over the lifetime of an individual, or selection over time, with adults that better cope with researcher disturbance having higher reproductive success and passing on these personalities to their offspring, could also be investigated. 


\section{Increased standardization and communication}

With the development of the internet and the global real-time availability of information across all researchers, much more attention should be paid to the construction of standardized protocols over large geographic areas (e.g., http://golondrinas.cornell.edu). Project-specific websites and listserves can help in all aspects of broadly based collaborations, from standardization of nestbox plans and construction to the design and execution of experiments to objectively evaluate changes to those designs.

\section{ACKNOWLEDGEMENTS}

We are grateful to all team members, colleagues and students for constructive discussions and suggestions. Jacques Blondel, Patty Gowaty, Kate Lessells and Tomasz Wesołowski kindly provided extensive remarks on an earlier version of the manuscript. Kristina Cockle, Peter Dunn, Paul Isenmann, Rimvydas Juškaitis, Kathy Martin, Eric Matthysen, Roger Prodon, Michael Schaub, Jaume Soler-Zurita and Linda Whittingham sent data on the design of their nestboxes or indicated interesting reprints or books.

\section{REFERENCES}

Alatalo R. V., Carlson A., Lundberg A. 1988. Nest cavity size and clutch size of Pied Flycatchers Ficedula hypoleuca breeding in natural tree-holes. Ornis Scand. 19: 317-319.

Ardia D. R., Perez J. H., Chad E. K., Voss M. A., Clotfelter E. D. 2009. Temperature and life history: experimental heating leads female tree swallows to modulate egg temperature and incubation behaviour. J. Anim. Ecol. 78: 4-13.

Ardia D. R., Perez J. H., Clotfelter E. D. 2006. Nest box orientation affects internal temperature aand nest site selection by Tree Swallows. J. Field Ornithol. 77: 339-344.

Atienzar F., Barba E., Holleman L. J. M., Belda E. J. 2009. Nesting habitat requirements and nestling diet in the Mediterranean populations of Crested Tits Lophophanes cristatus. Acta Ornithol. 44: 101-108.

Bai M.-L., Mühlenberg M. 2008. Sequential use of holes by birds breeding in a natural boreal forest in Mongolia. Bird Study 55: 161-168.

Bai M.-L., Wichmann F., Mühlenberg M. 2005. Nest-site characteristics of hole-nesting birds in a primeval boreal forest of Mongolia. Acta Ornithol. 40: 1-14.

Balandrin M. F., Klocke J. A., Wurtele E. S., Bollinger W. H. 1985. Natural plant chemical: sources of industrial and medicinal materials. Science 228: 1154-1160.

Barba E., Gil-Delgado J. A. 1990. Competition for nest-boxes among four vertebrate species: an experimental study in orange groves. Holarc. Ecol. 13: 183-186.

Baucells J., Camprodon J., Cerdeira J., Vila P. 2003. [Guide of the nest-boxes and feeders for birds and other vertebrates]. Lynx Edicions, Barcelona.
Bednarz J. C., Ripper D., Radley P. M. 2004. Emerging concepts and research directions in the study of cavity-nesting birds: keystone ecological processes. Condor 106: 1-4.

Blondel J. 1985. Breeding strategies of the Blue Tit and Coal Tit (Parus) in mainland and island Mediterranean habitats: a comparison. J. Anim. Ecol. 54: 531-556.

Blondel J., Aronson J., Bodiou J.-Y., Boeuf G. 2010. The Mediterranean Region. Biological Diversity in Space and Time. Second Edition. Oxford University Press.

Blondel J., Thomas D. W., Charmantier A., Perret P., Bourgault P., Lambrechts M. M. 2006. A thirty-year study of phenotypic and genetic variation of Blue Tits in Mediterranean habitat mosaics. BioScience 56: 661-673.

Bortolotti G. R. 1994. Effects of nest-box size on nest-site preference and reproduction in American kestrels. J. Raptor Res. 28: 127-133.

Both C., Artemyev A. V., Blaauw B., Cowie R. J., Dekhuijzen A. J., Eeva T., Enemar A., Gustafsson L., Ivankina E. V., Jarvinen A., Metcalfe N. B., Nyholm N. E. I., Potti J., Ravussin P. A., Sanz J. J., Silverin B., Slater F. M., Sokolov L. V., Török J., Winkel W., Wright J., Zang H., Visser M. E. 2004. Large-scale geographical variation confirms that climate change causes birds to lay earlier. Proc. R. Soc. Lond. B 271: 1657-1662.

Busse P., Olech B. 1968. [On some problems of birds spending nights in nestboxes]. Acta Ornithol. 11: 1-26.

Camprodon J., Salvanyà J., Soler-Zurita J. 2008. The abundance and suitability of tree cavities and heir impact on holenesting bird populations in beech forests of NE Iberian Peninsula. Acta Ornithol. 43: 17-31.

Carlson A., Sandström U., Olsson K. 1998. Availability and use of natural tree holes by cavity nesting birds in a Swedish deciduous forest. Ardea 86: 109-119.

Chamberlain D. E., Cannon A. R., Toms M. P., Leech D. I., Hatchwell B. J., Gaston K. J. 2009. Avian productivity in urban landscapes: a review and meta-analysis. Ibis 151: $1-18$.

Chapuisat M., Oppliger A., Magliano P., Christe P. 2007. Wood ants use resin to protect themselves against pathogens. Proc. R. Soc. Lond. B 274: 2013-2017.

Clutton-Brock T. H. (ed.) 1988. Reproductive Success. University of Chicago Press. Chicago.

Cockle K. L., Bodrati A. A. 2009. Nesting of the Planalto woodcreeper (Dendrocolaptes platyrostris). Wilson J. Ornithol. 121: 789-795.

Conner R. N. 1977. The effect of tree hardness on woodpecker nest entrance orientation. Auk 94: 369-370.

Cornelius C., Cockle K., Politi N., Berkunsky I., Sandoval L., Ojeda V., Rivera L., Hunter M. Jr., Martin K. 2008. Cavitynesting birds in Neotropical forests: cavities as a potentially limiting resource. Ornithol. Neotrop. 19: 253-268.

Czeszczewik D., Walankiewicz W. 2003. Natural nest sites of the Pied Flycatcher Ficedula hypoleuca in a primeval forest. Ardea 91: 221-229.

Dawson R. D., Lawrie C. C., O'Brien E. L. 2005. The importance of microclimate variation in determining size, growth and survival of avian offspring: experimental evidence from a cavity nesting passerine. Oecologia 144: 499-507.

Delmée E., Dachy P., Simon P. 1972. Contribution à la biologie des Mésanges (Paridae) en milieu forestier. Aves 9: 1-80.

Dhondt A. A. 2007. What drives differences between North American and Eurasian tit studies. In: Otter K. A. (ed.). Ecology and Behavior of Chickadees and Titmice: An Integrated Approach. Oxford University Press, pp. 299310.

Dhondt A. A., Adriaensen F. 1999. Experiments on competition between Great and Blue Tit: effects on Blue Tit reproductive success and population processes. Ostrich 70: 39-48. 
Dhondt A. A., Blondel J., Perret P. 2010. Why do Corsican Blue Tits Cyanistes caeruleus ogliastrae not use nest boxes for roosting? J. Ornithol. 151: 95-101.

Drilling N. E., Thompson C. F. 1988. Natal and breeding dispersal in House Wrens (Troglodytes aedon). Auk 105: 480-491.

East M. L., Perrins C. M. 1988. The effect of nestboxes on breeding populations of birds in broadleaved temperate woodlands. Ibis 130: 393-401.

Edington J. M., Edington M. A. 1972. Spatial patterns and habitat partition in the breeding birds of an upland wood. J. Anim. Ecol. 41: 331-357.

Eguchi K. 1980. The feeding ecology of the nestling Great Tit, Parus major minor, in the temperate ever-green broadleaved forest. II. With reference to breeding ecology. Researches on Population Ecology 22: 284-300.

Encabo S. I., Barba E., Gil-Delgado J. A., Monrós J. S. 2002. Geographical variation in egg size of the Great Tit Parus major: a new perspective. Ibis 144: 623-631.

Evans L. E., Ardia D. R., Flux J. E. C. 2009. Breeding synchrony through social stimulation in a spatially segregated population of European Starlings. Anim. Behav. 78: 671675.

Finch D. M. 1989. Relationships of surrounding riparian habitat to nest-box use and reproductive outcome in House Wrens. Condor 91: 848-859.

Garamszegi L. Z., Eens M., Török J. 2009. Behavioural syndromes and trappability in free-living collared flycatchers, Ficedula albicollis. Anim. Behav. 77: 803-812.

García-Navas V., Arroyo L., Sanz J. J., Díaz M. 2008. Effect of nestbox type on occupancy and breeding biology of Tree Sparrows Passer montanus in central Spain. Ibis 150: 356364.

Gill F. B. 2007. Ornithology. W. H. Freeman \& Co, New York.

Goodenough A. E., Hart A.G., Elliot S. L. 2008. Variation in offspring quality with cavity orientation in the Great Tit. Ethol. Ecol. Evol. 20: 375-389.

Gosler A. 2004. Birds in the hand. In: Sutherland W. J., Newton I., Green R. E. (eds). 2004. Bird Ecology and Conservation: a handbook of techniques. Oxford University Press, pp. 85-118.

Griffith S. C., Pryke S. R., Mariette M. 2008. Use of nest-boxes by the Zebra Finch (Taeniopygia guttata): implications for reproductive success and research. Emu 108: 311-319.

Gustafsson L., Nilsson S. G. 1985. Clutch size and breeding success of Pied and Collared Flycatchers Ficedula spp. in nestboxes of different sizes. Ibis 127: 380-385.

Haartman L. von 1969. The nesting habits of Finnish birds. Comm. Biologicae 32: 1-187. Societas scientiarum Fennica, Helsinki.

Hairston N. G. 1989. Ecological Experiments. Purpose, Design, and Execution. Cambridge University Press, Cambridge.

Hebda G. 2007. Characteristics of natural nest sites of the Blue Tits Cyanistes caeruleus, in oak hornbeam stands of the Odra River valley (SW Poland). Hole-breeding Passerines Meeting, book of abstract, p. 35 .

Heeb P., Kölliker M., Richner H. 2000. Bird-ectoparasite interactions, nest humidity, and ectoparasite community structure. Ecology 81: 958-968.

Holveck M.-J., Doutrelant C., Guerreiro R., Perret P., Gomez D., Grégoire A. (in press). Can eggs in a cavity be a female secondary sexual signal? Male nest visits and modelling of egg visual discrimination in blue tits. Biology Letters.

Hurlbert S. H. 1984. Pseudoreplication and the design of ecological field experiments. Ecol. Monographs 54: 187211.

Isenmann P. 1987. Geographic variation in clutch size: the example of the Blue Tit (Parus caeruleus) in the Mediterranean area. Vogelwarte 34: 93-99.
Jackson J. A., Jackson B. J. S. 2004. Ecological relationships between fungi and woodpecker cavity sites. Condor 106: $37-49$.

Janzen D. H. 1978. Complications in interpreting the chemical defences of trees against tropical arboreal plant-eating vertebrates. In: Montgomery G. G. (ed.). The Ecology of Arboreal Folivores. The Symposia of the National Zoological Park, Smithsonian Institution, Washington DC, pp. 73-84.

Järvinen A. 1989. Clutch-size variation in the Pied Flycatcher Ficedula hypoleuca. Ibis 131: 572-577.

Johnson L. S. 1996. Removal of old nest material from the nesting sites of House Wrens: effects on nest site attrac-tiveness and ectoparasite loads. J. Field Ornithol. 67: 212-221.

Johnson L. S., Kermott L. S. 1994. Nesting success of cavitynesting birds using natural cavities. J. Field Ornithol. 65: $36-51$.

Julliard R., McCleery R. H., Clobert J., Perrins C. M. 1997. Phenotypic adjustment of clutch size due to nest predation in the Great Tit. Ecology 78: 394-404.

Karlsson J., Nilsson S. G. 1977. The influence of nest-box area on clutch size in some hole-nesting passerines. Ibis 119: 207-211.

Kelly C. D. 2006. Replicating empirical research in behavioral ecology: how and why it should be done but rarely ever is. Q. Review Biol. 81: 221-236.

Kempenaers B., Dhondt A. A. 1991. Competition between blue and great tit for roosting sites in winter - an aviary experiment. Ornis Scand. 22: 73-75.

Kibler L. F. 1969. The establishment and maintenance of a Bluebird nest-box project. A review and commentary. BirdBanding 40: 114-129.

Kluijver H. N. 1951. The population ecology of the Great Tit, Parus m. major L. Ardea 39: 1-135.

Koch A. J., Munks S. A., Driscoll D., Kirkpatrick J. B. 2008. Does hollow occurrence vary with forest type? A case study in wet and dry Eucalyptus obliqua forest. Forest Ecol. Manage. 255: 3938-3951.

Koenig W. D., Gowaty P. A., Dickinson J. L. 1992. Boxes, barns, and bridges: confounding factors or exceptional opportunities in ecological studies? Oikos 63: 305-308.

Korpimäki E. 1985. Clutch size and breeding success in relation to nest-box size in Tengmalm's Owl Aegolius funereus. Holarctic Ecol. 8: 175-180.

Lack D. 1955. British tits (Parus spp.) in nesting boxes. Ardea 43: 50-84.

Lambrechts M. M., Perret P., Maistre M., Blondel J. 1999. Do experiments with captive non-domesticated animals make sense without population field studies? A case study with blue tits' breeding time. Proc. R. Soc. Lond. B 256: 13111315.

Lambrechts M. M., Schatz B., Bourgault P. 2008. Interactions between ants and breeding Paridae in two distinct Corsican oak habitats. Folia Zool. 57: 264-268.

Lesiński G. 2000. Location of bird nests in vertical metal pipes in suburban built-up area in Warsaw. Acta Ornithol. 35: 211-214.

Liedvogel M., Szulkin M., Knowles S. C. L., Wood M. J., Sheldon B. C. 2009. Phenotypic correlates of clock gene variation in a wild blue tit population: evidence for a role in seasonal timing. Mol. Ecol. 18: 2444-2456.

Llambias P. E., Fernández G. J. 2009. Effects of nestboxes on the breeding biology of Southern House Wrens Troglodytes aedon bonariae in the southern temperate zone. Ibis 151: 113-121.

Löhrl H. 1970. Unterschiedliche Bruthöhlenansprüche von Meisenarten und Kleibern als Beitrag zum Nischenproblem. Verhandlungsbericht der Deutchen Zoologischen Gesellschaft 64: 314-317. 
Löhrl H. 1973. Einfluß des Brutraumfläche auf die Gelegegröße der Kohlmeise (Parus major). J. Ornithol. 114: 339-347.

Löhrl H. 1977. Nistökologische und ethologische Anpassungserscheinungen bei Höhlenbrütern. Vogelwarte 29: 92-101.

Löhrl H. 1980. Weitere Versuche zur Frage "Brutraum und Gelegegröße bei der Kohlmeise (Parus major). J. Ornithol. 121: $403-405$.

Lundberg A., Alatalo R. V. 1992. The Pied Flycatcher. T. \& A. D. Poyser Ltd., London.

Mainwaring M. C., Hartley I. R. 2008. Covering nest boxes with wire mesh reduces Great Spotted Woodpecker Dendrocopos major predation of Blue Tit Cyanistes caeruleus nestlings, Lancashire, England. Conservation Evidence 5: 45-46.

Mänd R., Leivits A., Leivits M., Rodenhouse N. L. 2009. Provision of nestboxes raises the breeding density of Great Tits Parus major equally in coniferous and deciduous woodland. Ibis 151: 487-492.

Mappes T., Mappes J., Kotiaho J. 1994. Ectoparasites, nest choice and breeding success in the Pied Flycatcher. Oecologia 98: 147-149.

Martin K., Eadie J. M. 1999. Nest webs: a community-wide approach to the management and conservation of cavitynesting forest birds. Forest Ecol. Manage. 115: 243-257.

Martin K., Norris A. R. 2007. Life in the small-bodied cavitynester guild: Demography of sympatric mountain and Black-capped Chickadees with nest web communities under changing habitat conditions. In: Otter K. A. (ed.). Ecology and Behavior of Chickadees and Titmice. An Integrated Approach. Oxford University Press, pp. 111130.

Massoni V., Winkler D. W., Reboreda J. C. 2006. Brood parasitism of White-rumped Swallows by Shiny Cowbirds. J. Field Ornithol. 77: 80-84.

Matsuoka S. 2008. Wood hardness in nest trees of the Great Spotted Woodpecker Dendrocopos major. Ornithol. Sci. 7: 59-66.

Mazgajski T. D. 2007a. Effect of old nest material on nest site selection and breeding parameters in secondary hole nesters - a review. Acta Ornithol. 42: 1-14.

Mazgajski T. D. 2007b. Nest hole age decreases nest site attractiveness for the European Starling Sturnus vulgaris. Ornis Fennica 84: 32-38.

Mazgajski T. D. 2008. Hole using: adaptations and constraints. Acta Ornithol. 43: 1-2.

Mazgajski T. D., Rykowska Z. 2008. Dependence of nest mass on nest hole depth in the Great Tit Parus major. Acta Ornithol. 43: 49-55.

McCleery R. H., Clobert J., Julliard R., Perrins C. M. 1996. Nest predation and delayed cost of reproduction in the Great Tit. J. Anim. Ecol. 65: 96-104.

Mennerat A., Mirleau P., Blondel J., Perret P., Lambrechts M. M., Heeb P. 2009. Aromatic plants in nests of the Blue Tit Cyanistes caeruleus protect chicks from bacteria. Oecologia 161: 849-855.

Mennill D. J., Ratcliffe L. M. 2004. Nest cavity orientation in Black-capped Chickadees Poecile atricapillus: do the acoustic properties of cavities influence sound reception in the nest and extra-pair matings? J. Avian Biol. 35: 477482.

Mertens J. A. L. 1977. Thermal conditions for successful breeding in Great Tits (Parus major L.). I. Relation of growth and development of temperature regulation in nestling Great Tits. Oecologia 28: 1-29.

Mertens J. A. L. 1980. The energy requirements for incubation in Great Tits and other bird species. Ardea 68: 185-192.

Michelsons H. A. 1958. [Report on the overall results on attracting small forest hole-nesting birds in Latvian SSR[. In:
[Attraction of hole-nesting birds valuable for Latvian forests]. Proceedings of the Institute VI. Academy of Sciences of the Latvian SSR Press, Riga, pp. 1-72.

Miller K. E. 2002. Nesting success of the Great Crested Flycatcher in nest boxes and in tree cavities: are nest boxes safer from nest predation? Wilson Bull. 114: 179-185.

Moeed A., Dawson D. G. 1979. Breeding of Starlings (Sturnus vulgaris) in nest boxes of various types. New Zealand J. Zool. 6: 613-618.

Møller A. P. 1989. Parasites, predators and nest boxes: facts and artefacts in nest box studies of birds? Oikos 56: 421-423.

Møller A. P. 1992. Nest boxes and the scientific rigour of experimental studies. Oikos 63: 309-311.

Møller A. P. 2010. Interspecific variation in fear responses predicts urbanization in birds. Behav. Ecol. 21: 365-371.

Monrós J. S., Gómez J., Encabo S. I., Bradt S. 1999. Open nesting in Great Tits Parus major. Ardeola 46: 89-91.

Moreno J., Lobato E., Merino S., Martínez-de la Puente J. 2008. Blue-green eggs in Pied Flycatchers: an experimental demonstration that a supernormal stimulus elicits improved nestling condition. Ethology 114: 1078-1083.

Moreno J., Merino S., Lobato E., Rodríguez-Gironés M. A., Vásquez R. A. 2007. Sexual dimorphism and parental roles in the Thorn-tailed Rayadito (Furnariidae). Condor 109: 312-320.

Moreno J., Merino S., Vásquez R. A., Armesto J. J. 2005. Breeding biology of the thorn-tailed rayadito (Furnariidae) in south-temperate rainforests of Chile. Condor 107: 6977.

Moreno J., Morales J., Lobato E., Merino S., Tomás G., Martínez-de la Puente J. 2006. More colourful eggs induce a higher relative parental investment in the Pied Flycatcher Ficedula hypoleuca: a cross-fostering experiment. J. Avian Biol. 37: 555-560.

Nager R. G., van Noordwijk A. J. 1992. Energetic limitation in the egg-laying period of Great Tits. Proc. R. Soc. Lond. B 249: 259-263.

Newton I. (ed.). 1989. Lifetime Reproduction in Birds. Academic Press. London.

Newton I. 1994. The role of nest sites in limiting the numbers of hole-nesting birds: a review. Biol. Conserv. 70: 265-276.

Nilsson J. F., Stjernman M., Nillson J. A. 2008. Experimental reduction of incubation temperature affects both nestling and adult blue tits Cyanistes caeruleus. J. Avian Biol. 39: 553-559.

Nilsson S. G. 1975. [Clutch size and breeding success of birds in nest boxes and natural cavities]. Vår Fågelvärld 34: 207-211.

Nilsson S. G. 1984. The evolution of nest-site selection among hole-nesting birds: the importance of nest predation and competition. Ornis Scand. 15: 167-175.

Ojeda V. S., Suarez M. L., Kitzberger T. 2007. Crown dieback events as key processes creating cavity habitat for Magellanic Woodpeckers. Austral Ecol. 32: 436-445.

Orell M., Ojanen M. 1983. Breeding biology and population dynamics in the Willow Tit Parus monatnus. Ann. Zool. Fenn. 20: 90-114.

Orell M., Rytkönen S., Ilomäki K. 1993. Do Pied Flycatchers prefer nest boxes with old nest material? Ann. Zool. Fenn. 30: 313-316.

Pacejka A. J., Thompson C. F. 1996. Does removal of old nests from nestboxes by researchers affect mite populations in subsequent nests of House Wrens? J. Field Ornithol. 67: 558-564.

Perrins C. M. 1979. British Tits. Collins, London.

Pikula J., Beklova M. 1980. The nesting niches of the species of the genus Parus nesting in Czechoslovakia. Folia Zool. 29: 343-355. 
Pinowski J., Haman A., Jerzak L., Pinowska B., Barkowska M., Grodzki A., Haman K. 2006. The thermal properties of some nests of the Eurasian Tree Sparrow Passer montanus. J. Therm. Biol. 31: 573-581.

Purcell K. L., Verner J., Oring L. W. 1997. A comparison of the breeding ecology of birds nesting in boxes and tree cavities. Auk 114: 646-656.

Quine C. P., Fuller R. J., Smith K. W., Grice P. V. 2007. Stand management: a threat or opportunity for birds in British woodlands? Ibis 149: 161-174.

Remacha C., Delgado J. A. 2009. Spatial nest-box selection of cavity-nesting bird species in response to proximity to recreational infrastructures. Landscape Urban Plan. 93: $46-53$.

Remm J., Lőhmus A., Remm K. 2006. Tree cavities in riverine forests: what determines their occurrence and use by holenesting passerines? Forest Ecol. Manage. 221: 267-277.

Rendell W. B., Robertson R. J. 1989. Nest-site characteristics, reproductive success and cavity availability for tree swallows breeding in natural cavities. Condor 91: 875-885.

Rendell W. B., Robertson R. J. 1994. Cavity-entrance orientation and nest-site use by secondary hole-nesting birds. J. Field Ornithol. 65: 27-35.

Riddington R., Gosler A. G. 1995. Differences in reproductive success and parental qualities between habitats in the Great Tit Parus major. Ibis 137: 371-378.

Robertson B. A., Hutto R. L. 2006. A framework for understanding ecological traps and an evaluation of existing evidence. Ecology 87: 1075-1085.

Rytkönen S., Lehtonen R., Orell M. 1998. Breeding Great Tits Parus major avoid nestboxes infested with fleas. Ibis 140: 687-690.

Sanz J. J. 1998. Effects of geographic location and habitat on breeding parameters of Great Tits. Auk 115: 1034-1051.

Sanz J. J. 2003. Large-scale effect of climate change on breeding performance of Pied Flycatchers in Western Europe. Ecography 26: 45-50.

Schepps J., Lohr S., Martin T. E. 1999. Does tree hardness influence nest-tree selection by primary cavity nesters? Auk 116: 658-665.

Schlaepfer M. A., Runge M. C., Sherman P. W. 2002. Ecological and evolutionary traps. Trends Ecol. Evol. 17: 474-480.

Sengupta S. 1981. Adaptive significance of the use of margosa leaves in nests of the House Sparrows Passer domesticus. Emu 81: 114-115.

Seppänen J.-T., Forsman J. T. 2007. Interspecific social learning: novel preference can be acquired from a competing species. Curr. Biol. 17: 1248-1252.

Sipponen A., Peltola R., Jokinen J. J., Laitinen K., Lohi J., Rautio M., Männistö M., Sipponen P., Lounatmaa K. 2009. Effects of Norway Spruce (Picea abies) resin on cell wall and cell membrane of Staphylococcus aureus. Ultrastruct. Pathol. 33: 128-135.

Skwarska J. A., Kaliński A., Wawrzyniak J., Bańbura J. 2009 Opportunity makes a predator: Great Spotted Woodpecker predation on tit broods depends on nest box design. Ornis Fennica 86: 109-112.

Slagsvold T. 1975. Competition between the Great Tit Parus major and the Pied Flycatcher Ficedula hypoleuca in the breeding season. Ornis Scand. 6: 179-190.

Slagsvold T. 1987. Nest site preference and clutch size in the Pied Flycatcher Ficedula hypoleuca. Ornis Scand. 18: 189-197.

Slagsvold T. 1989. Experiments on clutch size and nest size in passerine birds. Oecologia 80: 297-302.

Slagsvold T., Amundsen T. 1992. Do Great Tits adjust hatching spread, egg size and offspring sex ratio to changes in clutch size? J. Anim. Ecol. 61: 249-258.
Slagsvold T., Wiebe K. L. 2007. Learning the ecological niche. Proc. R. Soc. Lond. B 274: 19-23.

Smith S. M. 1991. The Black-Capped Chickadee: Behavioral Ecology and Natural History. Cornell University Press, Ithaca, New York.

Soler J. J., Møller A. P., Soler M. 1998. Nest building, sexual selection and parental investment. Evol. Ecol. 12: 427441.

Sonerud G. A. 1989. Reduced predation by Pine Martens on nest of Tengmalm's Owl in relocated boxes. Anim. Behav. 37: 332-334.

Sorace A., Carere C. 1996. Occupation and breeding parameters in the Great Tit Parus major and in the Italian Sparrow Passer italiae in nestboxes of different size. Ornis Svecica 6: 173-177.

Sorace A., Petrassi F., Consiglio C. 2004. Long-distance relocation of nestboxes reduces nest predation by Pine Marten Martes martes. Bird Study 51: 119-124.

Tomás G., Merino S., Martínez-de la Puente, Moreno J., Morales J., Lobato E. 2008. A simple trapping method to estimate abundances of blood-sucking flying insects in avian nests. Anim. Behav. 75: 723-729.

Tripet F., Richner H. 1997. The coevolutionary potential of a 'generalist' parasite, the hen flea Ceratophyllus gallinae. Parasitol. 115: 419-427.

Tryjanowski P., Flux J. E. C., Sparks T. H. 2006. Date of breeding of the Starling Sturnus vulgaris in New Zealand is related to El Niño Southern Oscillation. Austral Ecol. 31: 634-637.

van Balen J. H. 1984. The relationship between nest-box size, occupation and breeding parameters of the Great Tit Parus major and some other hole-nesting species. Ardea 72: 163-175.

van Balen J. H., Booy C. J. H., Franeker van J. A., Osieck E. R. 1982. Studies of hole-nesting birds in natural nest sites. 1. Availability and occupation of natural nest sites. Ardea 70: $1-24$.

von Brömssen A., Jansson C. 1980. Effects of food addition to Willow Tit Parus montanus and Crested Tit P. cristatus at the time of breeding. Ornis Scand. 11: 173-178.

Van den Steen E., Pinxten R., Covaci A., Carere C., Eeva T., Heeb P., Kempenaers B., Lifjeld J., Massa B., Norte A. C., Orell M., Sanz J. J., Senar J. C., Sorace A., Eens M. 2010. The use of blue tit eggs as a biomonitoring tool for organohalogenated pollutants in the European environment. Sci. Total Environ. 408: 1451-1457.

Velky M., Kanuch P., Kristin A. 2010. Selection of winter roosts in the Great Tit Parus major: influence of microclimate. J. Ornithol. 151: 147-153.

Visser M. E., Adriaensen F., van Balen J. H., Blondel J., Dhondt A. A., van Dongen S., du Feu C., Ivankina E. V., Kerimov A. B., de Laet J., Matthysen E., McCleery R., Orell M., Thomson D. L. 2003. Variable responses to large-scale climate change in European Parus populations. Proc. R. Soc. Lond. B 270: 367-372.

Walankiewicz W. 1991. Do secondary cavity-nesting birds suffer more from competition for cavities or from predation in a primeval deciduous forest. Natural Areas J. 11: 203-212.

Wang N., Zhang Y., Zheng G. 2008. Breeding ecology of the Narcissus Flycatcher in North China. Wilson J. Ornithol. 120: 92-98.

Webb T. J., Noble D., Freckleton R. P. 2007. Abundance-occupancy dynamics in a human dominated environment: linking interspecific and intraspecific trends in British farmland and woodland birds. J. Anim. Ecol. 76: 123-134.

Wesołowski T. 1989. Nest-sites of hole-nesters in a primaeval temperate forest (Białowieża National Park, Poland). Acta Ornithol. 25: 321-351. 
Wesołowski T. 2007. Primeval conditions — what can we learn from them? Ibis 149: 64-77.

Wesołowski T., Czeszczewik D., Rowiński P., Walankiewicz W. 2002. Nest soaking in natural holes - a serious cause of breeding failure? Ornis Fennica 79: 132-138.

Wesołowski T., Rowiński P. 2004. Breeding behaviour of Nuthatch Sitta europaea in relation to natural hole attributes in a primeval forest. Bird Study 51: 143-155.

Wilson R. A., Manley P., Noon B. R. 1991. Covariance patterns among birds and vegetation in a California Oak woodland. USDA Forest Service Gen. Tech. Rep. PSW 126-135.

Zingg S., Arlettaz R., Schaub M. 2010. Nestbox design influences territory occupancy and reproduction in a declining, secondary cavity-breeding bird. Ardea 98: 67-75.

\section{STRESZCZENIE}

[Modele skrzynek lęgowych używanych do badań dziuplaków wtórnych: ich wpływ na uzyskiwane wyniki oraz niespójności metodyczne]

Szerokie wykorzystywanie sztucznych miejsc gniazdowych, jakimi są skrzynki lęgowe w badaniach dziuplaków, szczególnie drobnych gatunków wróblowych, doprowadziło do znacznego zwiększenia naszej wiedzy o ich ekologii, fizjologii i zachowaniu. Skrzynki lęgowe ułatwiają kontrole lęgów, eksperymentalne zabiegi, którym poddawane są jaja lub pisklęta oraz chwytanie, identyfikowanie i eksperymenty na ptakach dorosłych. Z drugiej strony tak częste wykorzystywanie sztucznych miejsc lęgowych prowadzi do powstania jak do tej pory pomijanego, ale potencjalnie istotnie wpływającego na uzyskiwane wyniki, efektu samych skrzynek - ich wymiarów, wysokości umieszczenia, sposobu konstrukcji, otwierania czy konserwacji.

$\mathrm{W}$ pracy podsumowano, $\mathrm{w}$ jakim zakresie publikacje naukowe dotyczące dziuplaków wtórnych dokumentują charakterystykę skrzynek lęgowych wykorzystywanych do badań (wymiary, kolor, materiał, z którego są wykonane itd.). Do analizy publikacje podzielono na te opublikowane przed i po roku 1992, ponieważ $\mathrm{w}$ tym roku ukazały się drukiem dwie prace zalecające $m$. in. dokładne opisywanie stosowanych skrzynek lęgowych. Należało zatem przyjąć, że w nowszych pracach (po 1992) właściwości skrzynek (wymiary, materiał, z którego są wykonane itd.) powinny być opisywane dokładniej. Jednakże analiza rozdziałów opisujących metody w łącznie 696 publikacjach wykazała, że w pracach publikowanych po 1992 informacje dotyczące wykorzystywanych $\mathrm{w}$ badaniach skrzynek są jeszcze bardziej fragmentaryczne (Fig. 1).

W pracy zwrócono uwagę, że skrzynki lęgowe są najczęściej ujednolicone, a ich charakterystyka odzwierciedla tylko część cech dziupli naturalnych. Należy pamiętać, że w przypadku dziupli naturalnych, zmienność, szczególnie wymiarów wewnętrznych, czy wysokości, na której są umieszczone, jest bardzo duża zarówno pomiędzy poszczególnymi gatunkami dziuplaków, jak i w obrębie tego samego gatunku (Tab. 1). Prócz tego analiza cech skrzynek lęgowych używanych przez różne zespoły badaczy wykazała, że nawet przy prowadzeniu badań na tym samym gatunku, stosowane skrzynki i metody mogą bardzo się różnić. Dużą wartością pracy jest zestawienie charakterystyk skrzynek lęgowych stosowanych do badań najpospolitszych dziuplaków, przede wszystkim w Europie (Apendyks 1).

$\mathrm{W}$ pracy podano listę typowych cech, charakteryzujących używane $\mathrm{w}$ badaniach skrzynki lęgowe, które powinny być zamieszczane $w$ publikacjach. W pracy wyjaśniono konieczność prezentowania takich informacji, podając przykłady, jak charakterystyka skrzynek lęgowych wpływa na dziuplaki. Na zakończenie przedstawiono kilka generalnych zagadnień związanych ze zmiennością wykorzystywanych do tej pory skrzynek lęgowych, które należałoby poddać badaniom. 


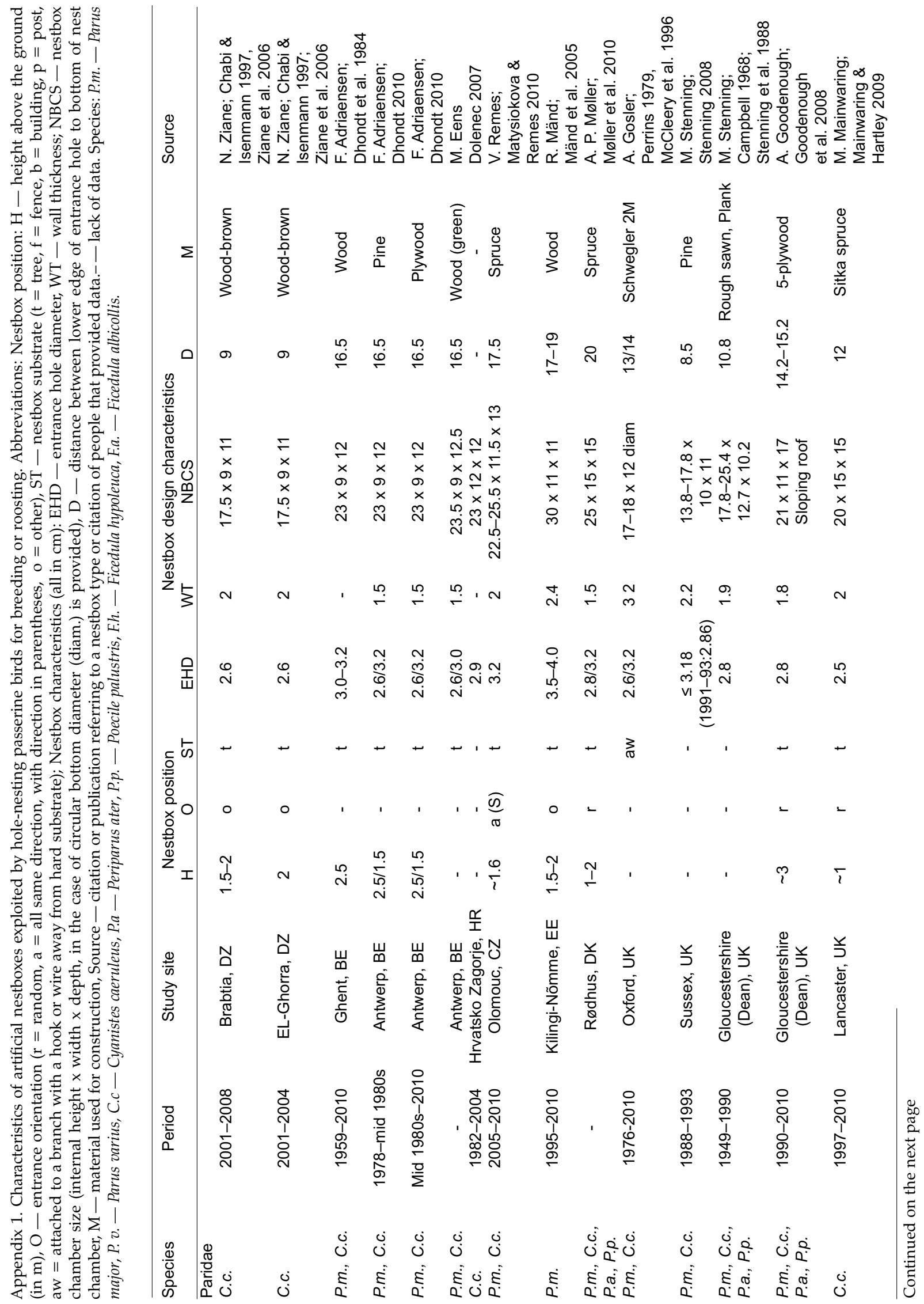




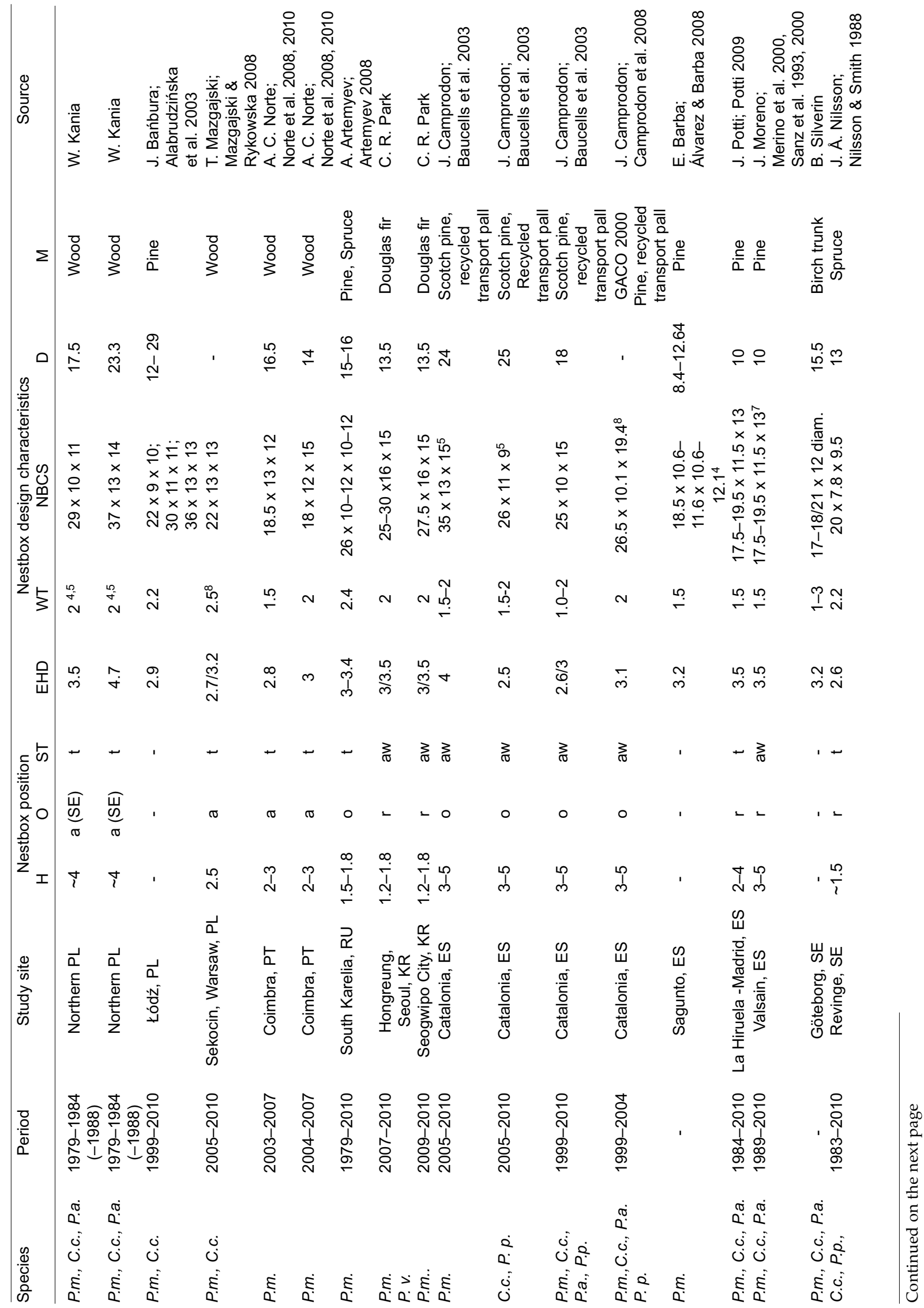




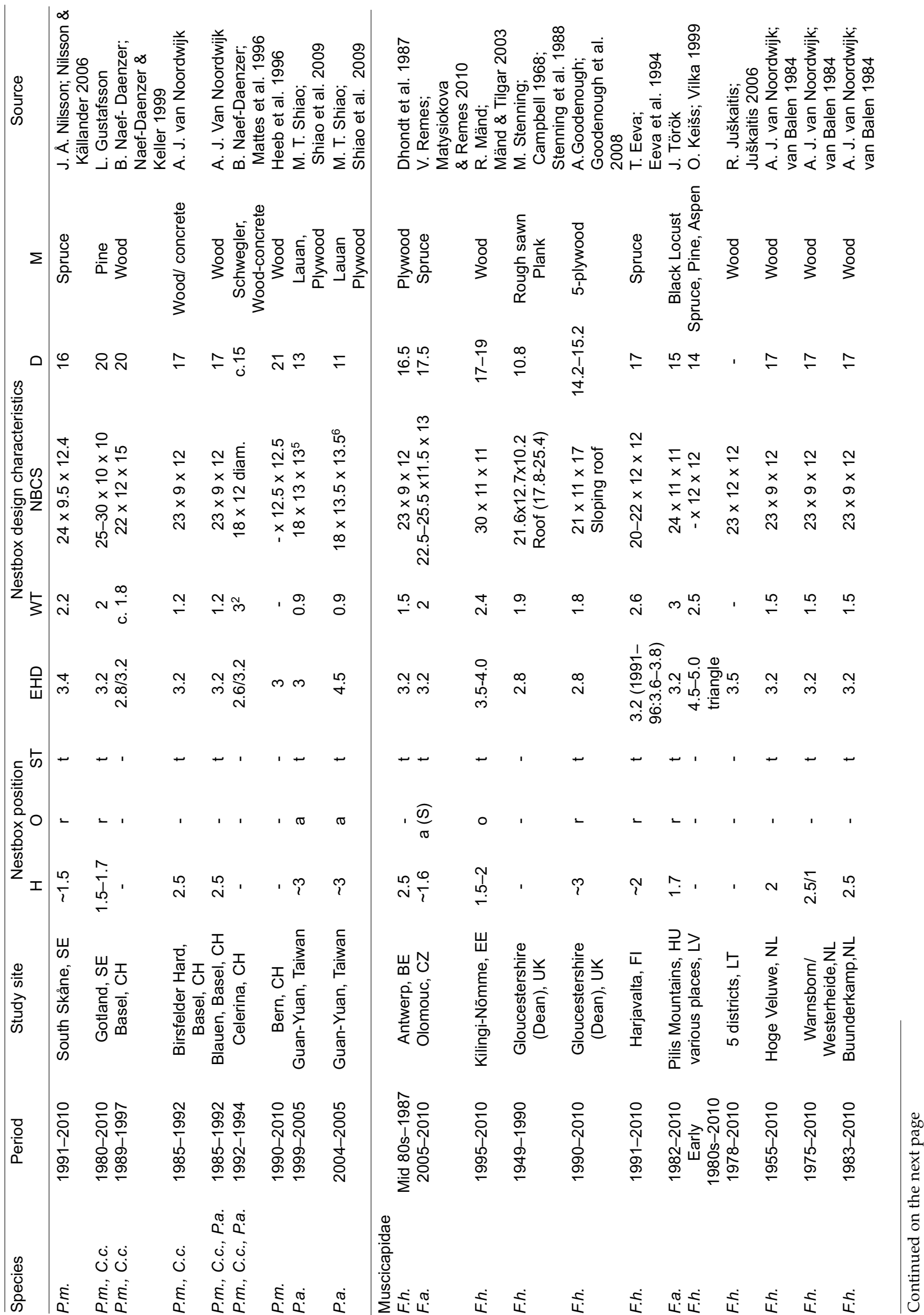




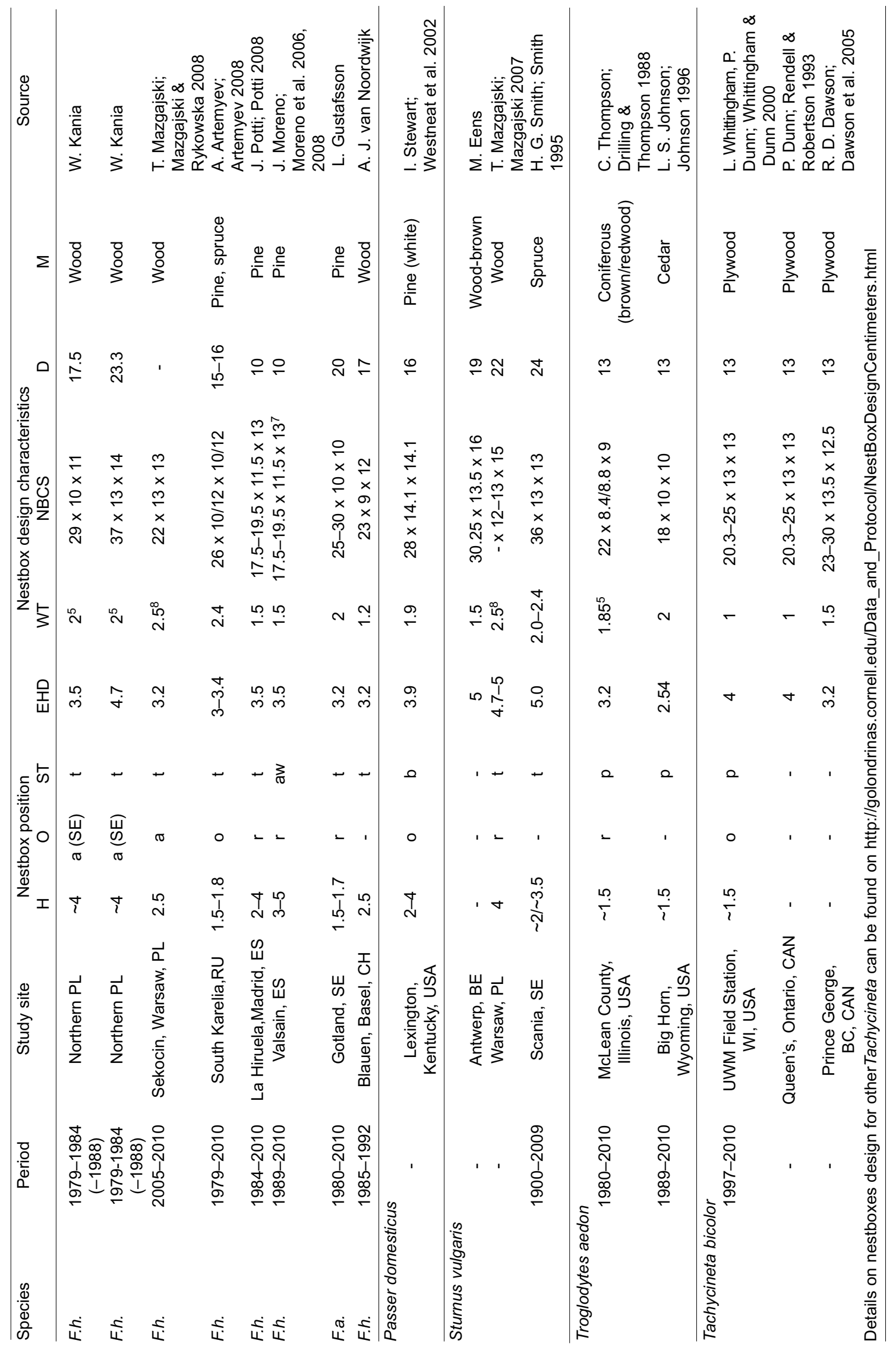




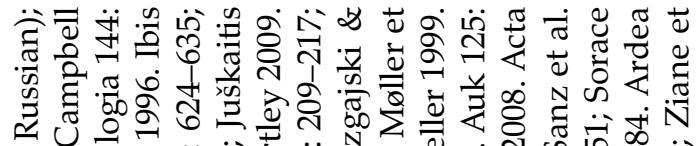

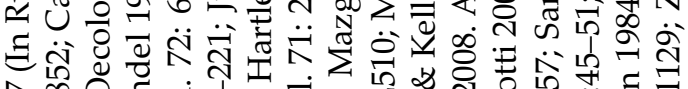

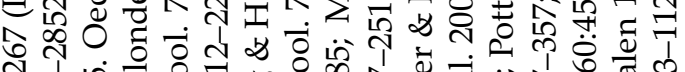
I bे

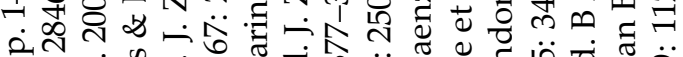

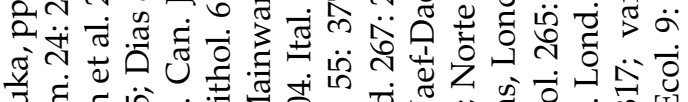

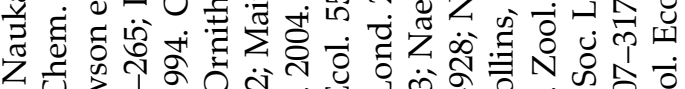

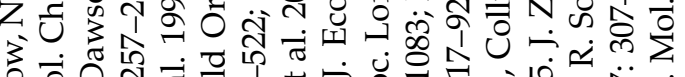

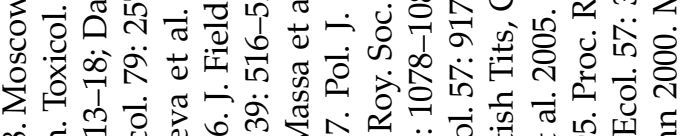

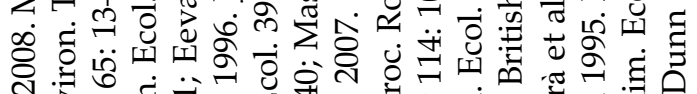

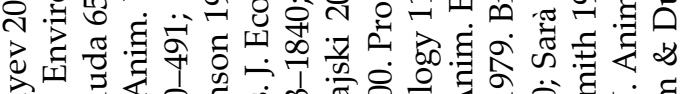

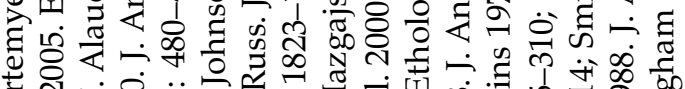

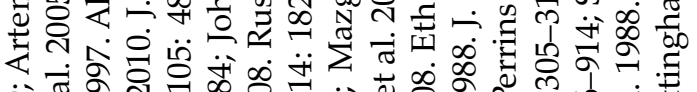

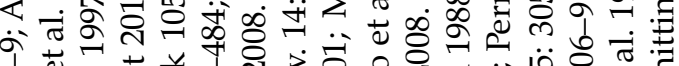

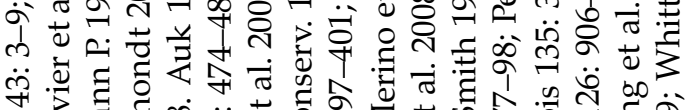
+

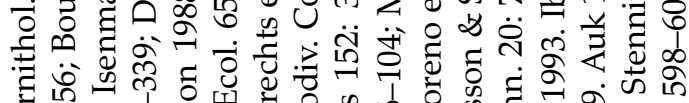

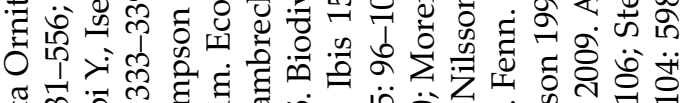

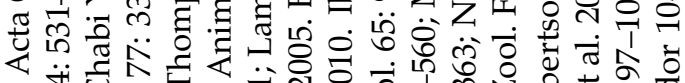

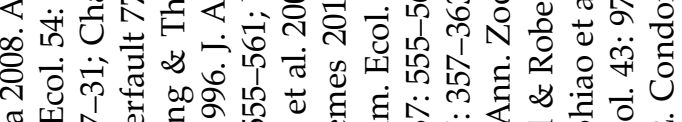

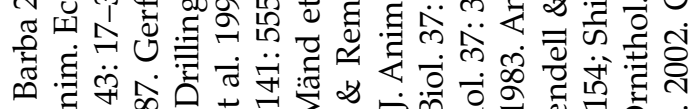

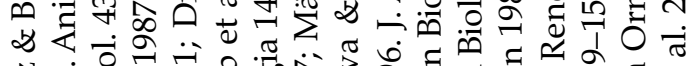
N

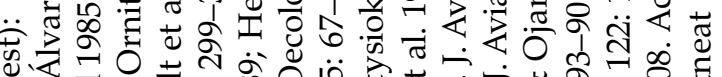

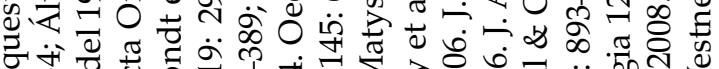

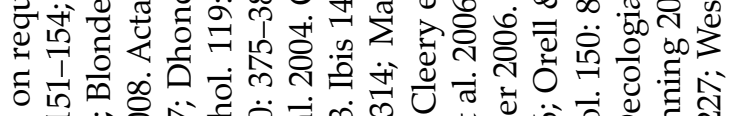

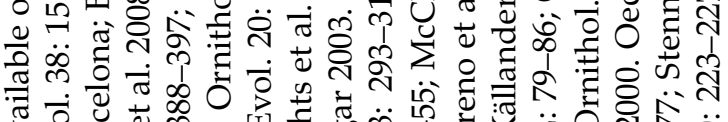

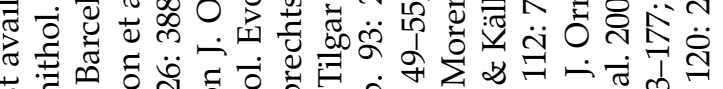

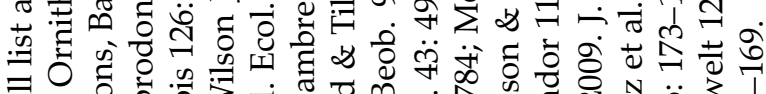

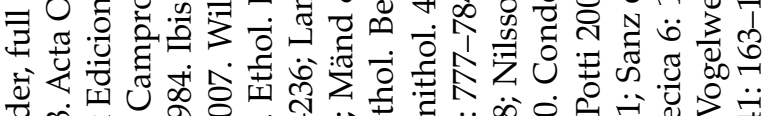

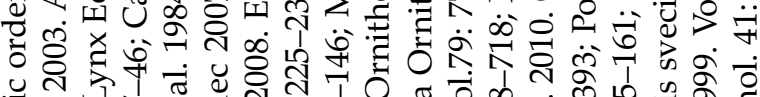

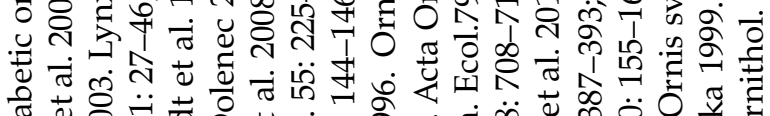

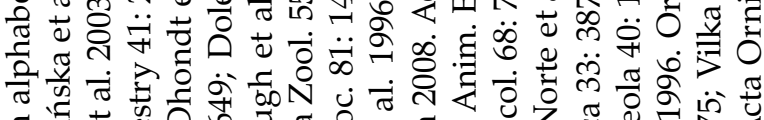

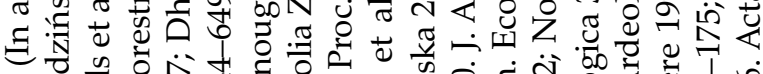

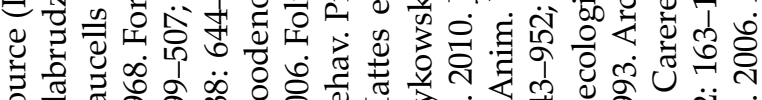

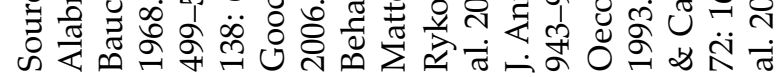


APPENDIX 2. Authors' contact information:

Marcel M. LAMBRECHTS

Centre d'Ecologie Fonctionnelle et Evolutive, UMR 5175, CNRS, 1919 route de Mende, 34293 Montpellier Cedex 5, FRANCE

Frank ADRIAENSEN

Evolutionary Ecology Group, University of Antwerp, Department of Biology, Campus CGB, B-2020 Antwerp, BELGIUM

Daniel R. ARDIA

Department of Biology, Franklin \& Marshall College, PO Box 3003, Lancaster, PA 17604, USA

\section{Alexandr V. ARTEMYEV}

Russian Academy of Sciences, Karelian Res. Ctr., Inst. Biol., Petrozavodsk 185610, RUSSIA

Francisco ATIÉNZAR,

"Cavanilles" Institute of Biodiversity and Evolutionary Biology, University of Valencia, Apartado Oficial 2085, E-46071 Valencia, SPAIN

Jerzy BAŃBURA

Department of Experimental Zoology \& Evolutionary Biology, University of Łódź, Banacha 12/16, 90-237 Łódź, POLAND

Emilio BARBA

Cavanilles" Institute of Biodiversity and Evolutionary Biology, University of Valencia, Apartado Oficial 2085, E-46071 Valencia, SPAIN

Jean-Charles BOUvIER

INRA, Plantes \& Systčmes de Culture Horticoles, UR 1115, 84000 Avignon, FRANCE

Jordi CAMPRODON

Biodiversity Department, Forest Technology Center of Catalonia, 25280 Solsona, Catalonia, SPAIN

Caren B. COOPER

Cornell Laboratory of Ornithology, 159 Sapsucker Woods Rd., Ithaca, NY 14850, USA

\section{Russell D. DAWSON}

Ecosystem Science and Management Program, University of Northern British Columbia, Prince George, BC Canada V2N 4Z9, CANADA
Marcel EENS

Campus Drie Eiken, Department of Biology (Ethology), Building C, B-2610 Antwerp (Wilrijk), BELGIUM

Tapio Eeva

Section of Ecology, 20014 University of Turku, FINLAND

\section{Bruno FAIVRE}

Université de Bourgogne, UMR CNRS 5561

BioGéoSciences, 6 Boulevard Gabriel, 21000 Dijon, FRANCE

Laszlo Z. GARAMSZEGI

Department of Evolutionary Ecology, Estación Biológica de Dońana - CSIC, 41092 Seville, SPAIN

Anne E. Goodenough

Department of Natural and Social Sciences, University of Gloucestershire, Glos GL50 4AZ, UK

Andrew G. GOSLER

Edward Grey Institute of Field Ornithology, South

Parks Road, Oxford OX1 3PS, UK

Arnaud GRÉGOIRE

Centre d'Ecologie Fonctionnelle et Evolutive, UMR 5175, Université de Montpellier II, 1919 route de Mende, 34293 Montpellier Cedex 5, FRANCE

\section{Simon C. GRIFFITH}

Department of Brain, Behaviour and Evolution, Macquarie University, Sydney, NSW 2109, AUSTRALIA

\section{Lars GUSTAFSSON}

Animal Ecology/Department of Ecology and Evolution, Evolutionary Biology Centre, Uppsala University, Norbyvägen 18d, S-752 36 Uppsala, SWEDEN

\section{Scott JoHnson}

Department of Biology, Towson University, Towson MD 21252, USA

Wojciech KANIA

Ornithological Station, Museum and Institute of Zoology, Polish Academy of Sciences, 80-680 Gdansk, POLAND 
Oskars KeIšs

Laboratory of Ornithology, Institute of Biology, University of Latvia; LV-2169 Salaspils, LATVIA

Paulo E. LLAMBiAS

Ecologia del Comportamiento Animal, CCT-MENDOZA CONICET, 5500 Mendoza, ARGENTINA

Mark C. MAINWARING

Lancaster Environment Centre, Lancaster University, Lancaster, LA1 4YQ, UK

Raivo MäND

Department of Zoology, Institute of Ecology and Earth Sciences, University of Tartu, 46 Vanemuise Str., Tartu, 51014, ESTONIA

Bruno MASSA

Stazione Inanellamento c/o Dipartimento SENFIMIZO, Università di Palermo, I-90128 Palermo, ITALY

Tomasz D. MAZGAJSKI

Museum and Institute of Zoology, Polish Academy of Sciences, Wilcza 64, 00-679, Warszawa, POLAND

Anders Pape MøLleR

Laboratoire Ecologie, Systematique et Evolution, UMR 8079 CNRS-Université Paris-Sud XIAgroParisTech, Batiment 362 Université Paris-Sud XI, F-91405 Orsay Cedex, FRANCE; Center for Advanced Study, Drammenveien 78, NO-0271 Oslo, NORWAY

Juan MORENO

Departamento de Ecología Evolutiva, Museo Nacional de Ciencias Naturales-CSIC, J. Gutiérrez Abascal 2, E-28006 Madrid, SPAIN

Beat Naef-DAENZER

Swiss Ornithological Institute, CH-6204 Sempach, SWITZERLAND

Jan-Åke NILSSON

Ecology Building, Animal Ecology, Lund University, 22362 Lund, SWEDEN

Ana C. NORTE

Institute of Marine Research, Department of Life Sciences, University of Coimbra, Apartado 3046, 3001-401 Coimbra, PORTUGAL
Markku ORELL

Department of Biology, University of Oulu, P. O. Box 3000 FI-90014, FINLAND

Ken A. OtTER

Ecosystem Science and Management Program, University of Northern British Columbia, Prince George, BC Canada V2N 4Z9, CANADA

Chan Ryul PARK

Warm-temperate Forest Research Center, Korea Forest Research Institute, Seogwipo City, Jejudo, SOUTH KOREA

Christopher M. PERRINS

Edward Grey Institute of Field Ornithology, South Parks Road, Oxford OX1 3PS, UK

Jan PINOWSKI

Center of Ecological Research, Polish Academy of Sciences, Dziekanów Leśny, PL 05092 Lomianki, POLAND

Jiri PORKERT

Gocarova 542, 50002 Hradec Kralove, CZECH REPUBLIC

Jaime POTTI

Department of Evolutionary Ecology, Estación Biológica de Dońana - Tr. Svobody 26, CSIC, 41092 Seville, SPAIN

Vladimir REMES

Laboratory of Ornithology, Department of Zoology, Palacky University, CZ-77146 Olomouc, CZECH REPUBLIC

Heinz RICHNER

University of Bern, Institute of Ecology \& Evolution (IEE), CH-3012 Bern, SWITZERLAND

Seppo RYTKÖNEN

Department of Biology, University of Oulu, P. O. Box 3000 FI-90014, FINLAND

Ming-Tang SHIAO

Wildlife laboratory, School of Forestry and Resource Conservation, National Taiwan University, Taipei 106, TAIWAN

Bengt SILVERIN

Department of Zoology, University of Göteborg, Box 463, 405 30, SWEDEN 
Tore Slagsvold

Centre for Ecological and Evolutionary Synthesis (CEES), Department of Biology, University of Oslo, P. O. Box 1066, Blindern, NO-0316 Oslo, NORWAY

Henrik G. SMITH

Ecology Building, Animal Ecology, Lund University, 22362 Lund, SWEDEN

Alberto SORACE

SROPU, Via R. Crippa 60, Rome, ITALY

Martyn J. STENNING

School of Life Sciences, University of Sussex, Falmer, Brighton, Sussex BN1 9QG, UK

Ian STEWART

Department of Biology, University of Kentucky, Lexington KY 40506-0225, USA

Charles F. THOMPSON

Behavior, Ecology, Evolution, and Systematics Section, School of Biological Sciences, Illinois State University, Normal, IL 61790-4120, USA
Janos TÖRÖK

Behavioural Ecology Group, Dept. Syst. Zool. \& Ecol., Eötvös University, H-1117, Budapest, Pázmány P. sétány 1/C, HUNGARY

Piotr TRYJANOWSKI

Institute of Zoology, Poznan University of Life Sciences, Wojska Polskiego 71 C, 60-625 Poznań, POLAND

Arie J. VAN NOORDWIJK

Netherlands Institute of Ecology, P. O. Box 40, NL 6666 ZG Heteren, THE NETHERLANDS

\section{David W. WINKLER}

Cornell University Museum of Vertebrates, Laboratory of Ornithology and Department of Ecology \& Evolutionary Biology, Ithaca, NY, 14853, USA

\section{Nadia ZiANE}

Laboratoire d'Ecophysiologie animale, Département de Biologie, B. P. 122300 Annaba, ALGÉRIE 